\title{
Catalytic Steam Reforming of Methanol to Produce Hydrogen on Supported Metal Catalysts
}

\author{
Raúl Pérez-Hernández, Demetrio Mendoza-Anaya, \\ Albina Gutiérrez Martínez and Antonio Gómez-Cortés
}

Additional information is available at the end of the chapter

http://dx.doi.org/10.5772/49965

\section{Introduction}

The use of fossil fuels for energy supply in the world has caused various global environmental problems. For this reason it is becoming progressively more important to find ways of providing environmentally friendly energy. One promising alternative to fossil fuels is hydrogen, due to the importance as a clean source of energy, as well as, the increased demand in chemical industry [1;2]. Also, fuel cells have recently attracted much attention as a potential device for energy transformation. Their performance is based on a clean process, without forming harmful by-products such as sulphur oxides and nitrogen oxides, while having a highly efficient energy transformation compared to conventional power generation processes as in heat engines. Hydrogen is a promising fuel for fuel cells and can be produced by steam reforming of natural gas, methanol and gasoline. At present, most of the world's hydrogen is produced from natural gas $\left(\sim 97 \% \mathrm{CH}_{4}\right)$ by a process called steam reforming [3-8]. The primary ways in which methane, is converted to hydrogen involve reaction with either steam (steam reforming), oxygen (partial oxidation), or both in sequence (autothermal reforming). In practice, gas mixtures containing carbon monoxide, carbon dioxide and unconverted methane. Reaction of carbon monoxide with steam (watergas shift) over a catalyst produces additional hydrogen and carbon dioxide, and after purification, high-purity hydrogen is recovered. This reaction is highly endothermic. Although stoichiometry for the SRM suggests that only one mole of water is required for one mole of methane $\left(\mathrm{CH}_{4}+\mathrm{H}_{2} \mathrm{O} \rightarrow \mathrm{CO}+3 \mathrm{H}_{2}\right)$, usually excess steam is used to reduce carbon formation. In most cases, carbon dioxide is vented into the atmosphere today, but there are options for capturing it in centralized plants for subsequent sequestration. However, steam reforming of methane does not reduce the use of fossil fuels and it still releases carbon to the environment in the form of $\mathrm{CO}_{2}$. Thus, to achieve the benefits of the hydrogen economy, it is necessary produce hydrogen from non-fossil resources, such as water, methanol or ethanol 
using a renewable energy source. Among the different feedstocks available, alcohols are very promising candidates because these are easily decomposed in the presence of water and generate hydrogen-rich mixture at a relatively lower temperature. Steam reforming (SR) of methanol has been extensively studied in recent years [1-7]. Methanol has a low boiling point, a high hydrogen/carbon ratio and no $\mathrm{C}-\mathrm{C}$ bonds, and can therefore be reformed at a relatively low temperature, reducing the risk of coke formation during the reaction [9]. Moreover, as methanol can be produced from renewable sources, its reforming does not contribute to a net addition of $\mathrm{CO}_{2}$ to the atmosphere. Methanol can be converted to hydrogen by the following three reactions:

Partial oxidation of methanol

$$
\mathrm{CH}_{3} \mathrm{OH}+0.5 \mathrm{O}_{2}=2 \mathrm{H}_{2}+\mathrm{CO}_{2} \quad \Delta \mathrm{H}^{\circ}=-192 \mathrm{~kJ} \mathrm{~mol}^{-1}
$$

Steam reforming of methanol

$$
\mathrm{CH}_{3} \mathrm{OH}+\mathrm{H}_{2} \mathrm{O}=3 \mathrm{H}_{2}+\mathrm{CO}_{2} \quad \Delta \mathrm{H}^{\circ}=50 \mathrm{~kJ} \mathrm{~mol}^{-1}
$$

Oxidative Steam Reforming of Methanol

$$
\mathrm{CH}_{3} \mathrm{OH}+1 / 2 \mathrm{H}_{2} \mathrm{O}+1 / 4 \mathrm{O}_{2}=\mathrm{CO}_{2}+5 / 2 \mathrm{H}_{2} \quad \Delta \mathrm{H}^{\circ}=0 \mathrm{~kJ} \mathrm{~mol}^{-1}
$$

Most studies reported in the literature for the steam reforming reaction were on the application of $\mathrm{CuO} / \mathrm{ZnO}$-based and $\mathrm{CuO} / \mathrm{ZnO} / \mathrm{Al}_{2} \mathrm{O}_{3}$-based catalysts [10-12]. Alumina is generally added to the catalysts to improve their surface area and mechanical strength, and to prevent catalyst sintering [13]. The in situ characterization of $\mathrm{CuO} / \mathrm{ZnO}$ reveals that the interaction of $\mathrm{Cu}$ and $\mathrm{ZnO}$ has a pronounced effect on the catalytic activity [14; 15]. Zinc oxide is known to improve the dispersion of $\mathrm{Cu}$ and the reducibility of $\mathrm{CuO}$. The improvement of reducibility has been proposed as a possible cause of the good activity of $\mathrm{CuO} / \mathrm{ZnO}$-based catalysts [16]. However, some researchers have proposed that the main reason is the improvement in the adsorption properties, including the adsorption of methanol [17] and the spillover of both hydrogen from $\mathrm{Cu}$ to $\mathrm{ZnO}$ [18] and oxygen species from $\mathrm{ZnO}$ to $\mathrm{Cu}$ [19]. $\mathrm{ZrO}_{2}$ addition to $\mathrm{Cu}$-based alumina-supported catalysts has been shown to increase methanol conversion and reduce CO yields [9; 20]. However, it has been noted that the metal-support interactions in $\mathrm{Cu} / \mathrm{ZrO}_{2}$ are different than in the more conventional $\mathrm{Cu} / \mathrm{ZnO}$ catalysts [21]. Some authors even describe a "synergy" between the $\mathrm{Cu}$ and $\mathrm{ZrO}_{2}$ [13]. The higher activity of $\mathrm{Cu}-\mathrm{ZrO}_{2}$ catalysts has also been attributed to the stabilization of $\mathrm{Cu}_{2} \mathrm{O}$ on the surface of the reduced catalysts or during the reaction [22; 23]. It is believed that the formation of $\mathrm{Cu}_{2} \mathrm{O}$ leads to both more active and more durable catalysts, since $\mathrm{Cu}_{2} \mathrm{O}$ is less susceptible to sintering compared with $\mathrm{Cu}$ metal $[22 ; 23]$. $\mathrm{Cu}^{+}$species have also been observed in $\mathrm{CeO}_{2}$-containing $\mathrm{Cu}$ catalysts $[24 ; 25]$ and isolated $\mathrm{Cu}^{2+}$ in lattice sites or in surface sites forming a nano-sized two-dimensional structure [26]. Addition of $\mathrm{CeO}_{2}$ to $\mathrm{Cu} / \mathrm{Al}_{2} \mathrm{O}_{3}$ catalysts has also been shown to increase methanol conversion, decrease $\mathrm{CO}$ selectivity and increase catalyst stability [27]. Due to this a strong effort has been directed to 
increase the overall efficiency of $\mathrm{CeO}_{2}$ for different applications. $\mathrm{CeO}_{2}$ has been widely used in purifying vehicle exhausts and became the most important rare oxides for NOx reduction with $\mathrm{CO}$ or hydrocarbons [28; 29]. Numerous studies of $\mathrm{ZrO}_{2}$ or $\mathrm{CeO}_{2}$ promoted Cu-based methanol steam reforming catalysts are available in the literature $[10 ; 12 ; 21 ; 25 ; 27 ; 30-34]$. However, comparing results between studies is challenging since the reaction evidently is very sensitive to the catalysts used and large differences in $\mathrm{Cu}$ loadings and catalyst compositions have been reported. For example, the copper concentrations on these types of catalysts have been varied from a few percent in some publications $[35 ; 36]$ up to $70 \%$ or above in others [13]. Other studies related with nickel based catalysts on the methanol reforming process has been reported [37-39] or ethanol (SRE) as an $\mathrm{H}_{2}$ source [40-44]. Navarro et al. [45] studied the oxidative reforming of hexadecane over $\mathrm{Ni}$ and Pt catalysts supported on $\mathrm{Ce} / \mathrm{La}$-doped $\mathrm{Al}_{2} \mathrm{O}_{3}$. They found for both $\mathrm{Ni}$ and Pt catalysts, higher specific activity when active metals were supported on alumina modified with cerium and lanthanum. However, the catalytic activity and $\mathrm{H}_{2}$ selectivity observed on Ni-based catalysts were higher than on Pt-based catalysts. Recently, Pd-ZnO catalyst systems have been reported to be active and selective for MSR after pre-reducing with $\mathrm{H}_{2}$ [46-48] and $\mathrm{Pd}$ supported on $\mathrm{ZrO}_{2}-\mathrm{TiO}_{2}$ [49]. Other catalytic systems containing highly dispersed gold have received great interest from both experimental and theoretical points of view. The role of metal oxide is to stabilize the gold nanoparticles and make the reaction take place on the gold surface reaction. Due to their high catalytic activity, particularly in CO oxidation at low temperature [50] gold-base catalysts are considered promising candidates for hydrogen production, through methanol decomposition and water-gas shift (WGS) reactions [51-54] catalytic combustion of volatile organic compounds (VOCs) [55], selective oxidation of CO in $\mathrm{H}_{2}$-rich gas [56], adsorption of $\mathrm{CO}$ on $\mathrm{Au} / \mathrm{CeO}_{2}$ catalysts [57]. Methanol steam reforming for $\mathrm{H}_{2}$ production has been not studied extensively with Au-base catalysts. Nevertheless, some gold-base catalysts has shown high activity for methanol oxidation at $373 \mathrm{~K}$ but low $\mathrm{H}_{2}$ production as a function of time on stream [58]. On methanol decomposition was reported that gold supported on $\mathrm{Al}_{2} \mathrm{O}_{3}$ was most active than on the $\mathrm{CeO}_{2}$, however, on the last catalyst the $\mathrm{H}_{2}$ selectivity was better than on the former catalyst on the range temperature of 300 to $500{ }^{\circ} \mathrm{C}$ [58]. But, when water was added in the feed they observed a slight increase in the methanol conversion and, changes in the products distribution. The catalytic activity of the $\mathrm{Au}-\mathrm{Ag} / \mathrm{CeO}_{2}$ catalyst and silver supported on $\mathrm{ZnO} 1 \mathrm{D}$ rods catalysts on the steam reforming methanol reaction for hydrogen production was reported [59-61]. The catalytic activity on $\mathrm{Ag} / \mathrm{ZnO}$ sample with low Ag content showed better performance on the SRM reaction than on high silver loading catalyst. So, the sample with small Ag particle size showed best performance in methanol conversion than catalyst with big Ag particle size. Our group has previously studied the effect of nickel-copper addition to $\mathrm{ZrO} 2$ by impregnation method and compared the catalytic activity of these bimetallic $\mathrm{Cu} / \mathrm{Ni}$ catalysts on the oxidative steam reforming of methanol to produce $\mathrm{H}_{2}$ [39]. The reactivity of the catalysts showed that the bimetallic samples prepared by successive impregnation had highest catalytic activity among all the catalysts studied. 
The goal of this chapter is showed the effect of the metal copper or nickel addition to $\mathrm{CeO}_{2}$ prepared by co-impregnation and sequential impregnation. Catalytic performance in oxidative steam reforming of methanol for the three $\mathrm{Cu}-\mathrm{Ni}$ catalysts was compared with corresponding monometallic $\mathrm{Cu}$ and Ni catalysts, and $\mathrm{Au} / \mathrm{CeO}_{2}$ catalysts. The comparison is also made with characterization results obtained by BET ( $\mathrm{N}_{2}$ adsorption-desorption), SEM (Scanning Electron Microscopy), EDX (Energy Dispersive X-ray Spectroscopy), XRD (X-ray Diffraction), TEM (Transmission Electron Microscopy) and TPR (Temperature Programmed Reduction). In addition, the relation between the structure of bimetallic particles and catalytic performance in oxidative steam reforming of methanol is discussed.

\section{Experimental}

\subsection{Synthesis of the catalysts}

The $\mathrm{CeO}_{2}$ synthesis was done using the precipitation method of the $\mathrm{Ce}\left(\mathrm{NO}_{3}\right)_{3} \bullet 6 \mathrm{H}_{2} \mathrm{O}$ (Aldrich) in $\mathrm{NH}_{4} \mathrm{OH}$ (Fluka) at room temperature (r.t.).

$$
\begin{gathered}
8 \mathrm{Ce}\left(\mathrm{NO}_{3}\right)_{3} \bullet 6 \mathrm{H}_{2} \mathrm{O}+22 \mathrm{NH}_{4} \mathrm{OH} \leftrightarrow 8 \mathrm{Ce}(\mathrm{OH})_{4} \downarrow+23 \mathrm{NH}_{4} \mathrm{NO}_{3}+41 \mathrm{H}_{2} \mathrm{O} \\
\mathrm{Ce}(\mathrm{OH})_{4} \stackrel{\Delta}{\longrightarrow} \mathrm{CeO}_{2}+2 \mathrm{H}_{2} \mathrm{O}
\end{gathered}
$$

The solid obtained was dried at $100{ }^{\circ} \mathrm{C}$ and then heated at $650^{\circ} \mathrm{C}$ for 5 hours in air stream. The prepared supports were impregnated with a solution of $\mathrm{NiCl}_{2} \bullet 6 \mathrm{H}_{2} \mathrm{O}$, and another with a solution of $\mathrm{Cu}\left(\mathrm{CH}_{3}-\mathrm{CO}_{2}\right)_{2} \bullet \mathrm{H}_{2} \mathrm{O}$ at an appropriate concentration to yield $3 \mathrm{wt} \%$ of copper and nickel respectively. Three bimetallic samples were prepared at $50 \% \mathrm{Cu}$ and $50 \% \mathrm{Ni}$ respectively to obtain $3 \mathrm{wt}$. \% of total metallic phase. For the first sample, $\mathrm{CeO}_{2}$ support was successively impregnated with an aqueous solution of $\mathrm{Cu}\left(\mathrm{CH}_{3} \mathrm{COO}\right)_{2} \bullet \mathrm{H}_{2} \mathrm{O}$ (Merck), after that, the excess of water was removed at $80{ }^{\circ} \mathrm{C}$ under constant stirring and the catalyst was dried at $110{ }^{\circ} \mathrm{C}$ and calcined at $500{ }^{\circ} \mathrm{C}$ for $2 \mathrm{~h}$ followed by cooling down to r.t. Then, an aqueous solution of $\mathrm{NiCl}_{2} \bullet 6 \mathrm{H}_{2} \mathrm{O}$ was added and the resulting solid was calcined at the same temperature and time. The as prepared catalysts will be referred as $\mathrm{Ni} / \mathrm{Cu} / \mathrm{CeO}_{2}$. For the second catalyst, the synthesis procedure was changed to the above sample mentioned. The labeling of this catalyst will be referred as $\mathrm{Cu} / \mathrm{Ni} / \mathrm{CeO}_{2}$. The third sample $\left(\mathrm{Cu}-\mathrm{Ni} / \mathrm{CeO}_{2}\right)$ was prepared by using a simultaneous impregnation (also called co-impregnation): an aqueous solution of $\mathrm{Cu}\left(\mathrm{CH}_{3} \mathrm{COO}\right)_{2}$ and $\mathrm{NiCl}_{2} \bullet 6 \mathrm{H}_{2} \mathrm{O}$ were added to $\mathrm{CeO}_{2}$ and calcined at $500{ }^{\circ} \mathrm{C}$ for $2 \mathrm{~h}$. All the samples were reduced at $400{ }^{\circ} \mathrm{C}$ using a mixture of $\mathrm{H}_{2}(5 \%) / \mathrm{He}(50 \mathrm{~mL} / \mathrm{min})$ stream for $1 \mathrm{~h}$ before characterization, except for TPR technique in which the sample was calcined.

\subsection{Characterization}

The details of catalysts characterization have been reported in our earlier reports $[26 ; 28 ; 37$; $38 ; 49 ; 59 ; 61-64]$. Nitrogen adsorption-desorption of the samples was measured at $-196 \mathrm{C}$ on a Belsorp-max Bel Japan equipment. Prior to the measurements the samples were degassed at $150{ }^{\circ} \mathrm{C}$ for $1 \mathrm{~h}$. The surface area and pore size distribution were determined using the BET 
and $\mathrm{BJH}$ methods respectively. HRTEM and local chemical analysis of the bimetallic nanoparticles were carried out in a JEM 2200FS microscope with a resolution of $0.19 \mathrm{~nm}$ and fitted with an energy dispersive X-ray Spectrometer (NORAN) and a JEM 2010-HT with a point resolution of $0.19 \mathrm{~nm}$ fitted with an EDX microprobe Thermo-scientific. JEOL-2010 microscope with a point resolution of $0.19 \mathrm{~nm}$ fitted with an NORAN microprobe Thermoscientific. The samples were dispersed in isopropanol and a drop of such a solution was placed onto copper and gold 300 mesh grids. Surface properties of the catalysts were studied by CO adsorption followed by DRIFT (Fourier Transform Infrared Spectroscopy). Experiments were done in a Nicolect Nexus 470 Spectrometer equipped with environmentally controlled Spectra Tech DRIFT (Diffuse Reflectance Infrared Fourier Transform) cell with $\mathrm{KBr}$ windows. For each experiment, $0.025 \mathrm{~g}$ of the sample was packed in the sample holder and pretreated in-situ under $\mathrm{H}_{2}$ flow $(30 \mathrm{~mL} / \mathrm{min})$ at $300{ }^{\circ} \mathrm{C}$ for $1 \mathrm{~h}$. After this treatment the sample was purged with helium flow for half hour and cooled to room temperature in the same gas atmosphere before admittance for $5 \mathrm{~min}$ a flow (30 $\mathrm{mL} / \mathrm{min}$ ) of $2.5 \% \mathrm{CO}$ diluted in He. Afterwards, pure He was allowed to flow in the system to eliminate the residual CO gas. Spectra were collected from 128 scans with resolution of 4 $\mathrm{cm}^{-1}$. For all catalysts a FTIR spectrum was obtained by making reference to the freshly reduced solid prior to $\mathrm{CO}$ adsorption. The spectrum of dry KBR was taken for IR singlebeam background subtraction. Oxidative steam reforming of methanol was carried out at an atmospheric pressure by placing the fixed bed flow reactor $(8 \mathrm{~mm}$ i.d.) in an electric furnace consisting of two heating zones equipped with omega temperature controllers, using a commercial flow system RIG-100-ISRI. Prior to OSRM reaction, $0.05 \mathrm{~g}$ of catalyst diluted in $0.150 \mathrm{~g}$ of $\mathrm{SiC}$ was reduced in situ, using a stream of $\mathrm{H}_{2}(50 \mathrm{~mL} / \mathrm{min})$ increasing temperature from room to $400{ }^{\circ} \mathrm{C}$ with a heating rate of $10{ }^{\circ} \mathrm{C} / \mathrm{min}$ and holding this temperature for $1 \mathrm{~h}$. A thermocouple in contact with the catalytic bed was utilized in order to monitor and control the temperature inside the catalyst. For the reaction, $\mathrm{O}_{2}(5 \%) / \mathrm{He}$ mixture $(50 \mathrm{~mL} / \mathrm{min})$ and $150 \mathrm{~mL} / \mathrm{min}$ of He was passed through stainless steel saturator containing methanol and water mixture (we use a hot line in the saturator in order to maintain constant the temperature $\sim 25^{\circ} \mathrm{C}$ ). This gas was added by means of a mass flow controller (RIG-100). The total flow rate was kept at $200 \mathrm{~mL} / \mathrm{min}$. Reaction products were analyzed by Gow-Mac 580 Gas chromatograph with thermal conductivity detector equipped with two columns system (molecular sieve $5 \AA$ and Porapack $Q$ columns), double injector controlled by Clarity software V.2.6.04.402 and TCD. The first column was used to separate the gaseous products such as $\mathrm{H}_{2}, \mathrm{O}_{2}, \mathrm{CH}_{4}$ and $\mathrm{CO}$. The second column was used to separate water, methanol, methyl formate (MF) and $\mathrm{CO}_{2}$. All the reported data were collected after a run time of $7 \mathrm{~h}$. The following equations were used to determine the methanol conversion and selectivity:

$$
X(\%)=\frac{C_{\text {in }}-C_{\text {out }}}{C_{\text {in }}} * 100 S_{\mathrm{CO}_{2}}(\%)=\frac{n \mathrm{CO}_{2-\text { out }}}{n \mathrm{CO}_{2-\text { out }}+n \mathrm{CO}_{\text {out }}} * 100
$$

and/or

$$
S_{H_{2}}(\%)=\frac{n H_{2-o u t}}{n H_{2-o u t}+n C H_{4-o u t}+n C O_{2 o u t}+C O} * 100
$$


The subscripts in and out indicate the inlet and the outlet concentrations of the reactants or products.

\section{Results}

\section{1. $\mathrm{Ni} / \mathrm{Cu} / \mathrm{CeO}_{2}$ system}

\subsubsection{Textural properties of the $\mathrm{Cu}-\mathrm{Ni} / \mathrm{CeO}_{2}$ system}

Table 1 showed the textural properties of the catalytic materials obtained from $\mathrm{N}_{2}$ physisorption measurement at temperature of liquid nitrogen. It showed that doping the bare $\mathrm{CeO}_{2}$ support with copper or nickel to obtain the monometallic catalysts, results in a slight decrease on the BET surface area. The same effect was observed on the bimetallic samples, when $\mathrm{Cu}$ and $\mathrm{Ni}$ were impregnated by successive or co-impregnation method on the $\mathrm{CeO}_{2}$. Typical SEM image with backscatter analysis of the as-synthesized $\mathrm{Cu}-\mathrm{Ni} / \mathrm{CeO}_{2}$ catalyst prepared by co-impregnation method is present in Fig. 1. It showed that the sample is composed by irregular particles. It is important to mention that the bare $\mathrm{CeO}_{2}$, as well as, the other catalysts under study had the same morphology, as the sample present on Fig. 1. This is expected because we used the $\mathrm{CeO}_{2}$ previously stabilized at $650{ }^{\circ} \mathrm{C}$ to obtain the catalysts.

\begin{tabular}{lcc}
\hline & Sample & \multicolumn{1}{c}{$\mathbf{m}^{2} / \mathrm{g}$} \\
\hline $\mathrm{CeO} 2$ & 40.1 \\
\hline $\mathrm{Cu} / \mathrm{CeO}_{2}$ & 34.5 \\
\hline $\mathrm{Cu} / \mathrm{Ni} / \mathrm{CeO}_{2}$ & 25.7 \\
\hline $\mathrm{Cu}-\mathrm{Ni} / \mathrm{CeO}_{2}$ & 30.4 \\
\hline $\mathbf{N i} / \mathrm{Cu}_{2} / \mathrm{CeO}_{2}$ & 27.5 \\
\hline $\mathbf{N i} / \mathrm{CeO}_{2}$ & 28.6 \\
\hline
\end{tabular}

Table 1. Specific surface area (BET) of the Ni/Cu-base catalysts.

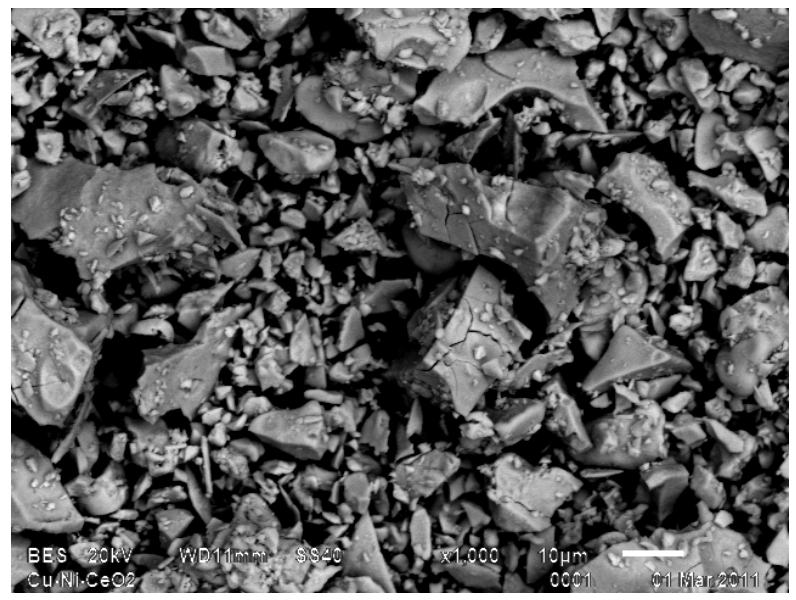

Figure 1. Typical SEM image of the fresh $\mathrm{Ni}-\mathrm{Cu} / \mathrm{CeO}_{2}$ prepared by co-impregnation. 


\subsubsection{Crystalline phases of the $\mathrm{Cu}-\mathrm{Ni} / \mathrm{CeO}$ catalysts}

Fig. 2 showed the XRD patterns of the $\mathrm{Ni} / \mathrm{Cu} / \mathrm{CeO}_{2}$ catalysts after thermal treatments (calcination and reduction). XRD patterns of the $\mathrm{Ni} / \mathrm{Cu}$-base catalysts yield a typical cubic fluorite structure of ceria, in addition, diffraction peak attributed to the metallic Ni was observed at $2 \Theta=44.735$ on the $\mathrm{Ni} / \mathrm{CeO}_{2}$ sample, indicating that $\mathrm{NiO}$ was completely reduced to metallic $\mathrm{Ni}$ below $500{ }^{\circ} \mathrm{C}$. On $\mathrm{Cu} / \mathrm{CeO}_{2}$ sample diffraction-peaks of metallic $\mathrm{Cu}$ were observed at $2 \Theta=43.317$ and 50.449 (JCPDS 85-1326) respectively. On the bimetallic samples, diffraction peaks of $\mathrm{Cu}, \mathrm{Ni}$ or $\mathrm{Cu}-\mathrm{Ni}$ alloy were not observed, although the samples suffer different thermal treatments; this could be due to its low metal concentration $(3.0 \mathrm{wt} \%)$ or because the particle size of the active phase is below of the detection limit of the technique. On samples with 3 wt. \% of $\mathrm{Cu} / \mathrm{Ni}$ supported on $\mathrm{ZrO}_{2}$ [39] was observed the same effect. So, no diffraction peaks of metallic phase were observed by XRD technique.

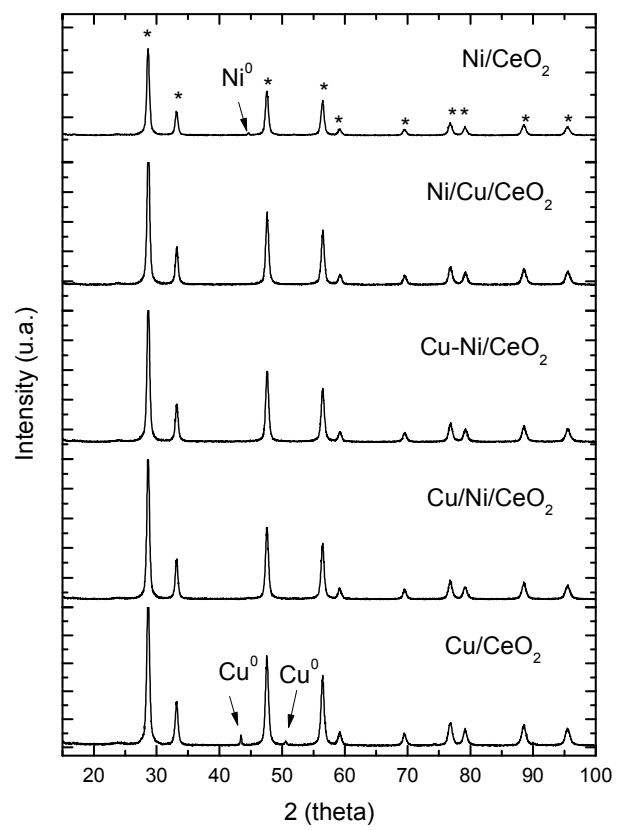

Figure 2. $\mathrm{XRD}$ patterns of the $\mathrm{Ni} / \mathrm{Cu} / \mathrm{CeO} 2$ catalysts. $\left.{ }^{*}\right]$ cubic $-\mathrm{CeO} 2$

\subsubsection{Temperature-programmed reduction of the $\mathrm{Cu}$-Ni-base catalysts supported on $\mathrm{CeO}_{2}$}

Hydrogen consumption curves of the fresh bimetallic $\mathrm{Cu} / \mathrm{Ni}$-base catalysts and samples after catalytic reaction are shown in Fig. 3. Although the position of the reduction peaks strongly depends of the particle size or the interaction between metal active phase and the support, the TPR profiles of the catalytic materials are included for comparison. TPR profile of the bare $\mathrm{CeO}_{2}$ sample showed a broad peak above $500{ }^{\circ} \mathrm{C}$, this is assigned to reduction of surface ceria. Calcined $\mathrm{CuO} / \mathrm{CeO}_{2}$ catalyst showed three reduction peaks below $300{ }^{\circ} \mathrm{C}$ 


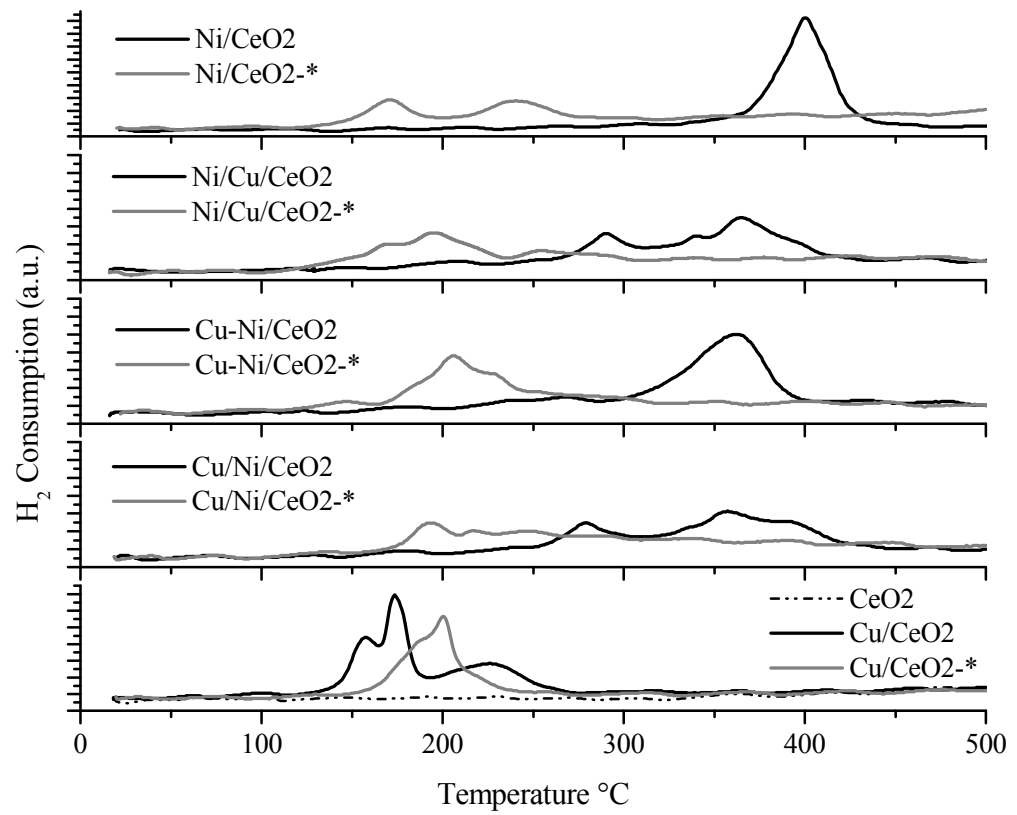

Figure 3. Temperature-programmed reduction profiles of the fresh $\mathrm{Cu} / \mathrm{Ni} / \mathrm{CeO}_{2}$ catalysts (solid line) and samples after catalytic reaction (clear line).

indicating the presence of different kinds of $\mathrm{Cu}$ species formed during the preoxidation step [26; 63]. Peaks below $200{ }^{\circ} \mathrm{C}$ were attributed to reduction of highly dispersed $\mathrm{CuO}$ and the peak above $200{ }^{\circ} \mathrm{C}$ was associated with the reduction of the $\mathrm{CuO}$ bulk. The $\mathrm{NiO} / \mathrm{CeO}_{2}$ catalyst showed a sharp reduction peak at around $400{ }^{\circ} \mathrm{C}$ and may be attributed to reduction of $\mathrm{NiO}$ to metallic Ni crystallites. This temperature is higher than that the reported in previous work [38] for a similar catalyst. In that case the Nickel precursor was $\mathrm{Ni}\left(\mathrm{NO}_{3}\right)_{2} \bullet 6 \mathrm{H}_{2} \mathrm{O}$ which indicates different interaction between $\mathrm{NiO}$ and $\mathrm{CeO}_{2}$. TPR profile of the bimetallic catalysts showed reduction peaks at lower temperature than $\mathrm{Ni} / \mathrm{CeO}_{2}$ catalyst. It has been reported that $\mathrm{NiO}$ supported, could be reduced at low temperatures when $\mathrm{Cu}$ or $\mathrm{Pt}$ are presented [37; 39; 65]. Because, $\mathrm{Cu}$ or $\mathrm{Pt}$ causes spillover of hydrogen onto $\mathrm{Ni}$, inducing a simultaneous reduction of both, copper (platinum) oxide and $\mathrm{NiO}$, causing a shift in the reduction of the active phase at low temperatures. In addition, it has been suggested that the first reduction peak observed in the TPR profile of the bimetallic catalyst, corresponded to the reduction of adjacent $\mathrm{Cu}$ and $\mathrm{Ni}$ atoms, which could be forming a bimetallic phase $[37 ; 39 ; 65]$. This finding indicates that the bimetallic phase had different interaction with the support and promoted the nickel reduction at lower temperatures and slows the copper reduction. In addition, it is clear that the bimetallic samples prepared by successive impregnation showed a broader reduction peak at higher temperatures than that for the $\mathrm{Cu} / \mathrm{CeO}_{2}$ sample, suggesting a broad particle size distribution, and slightly lower than $\mathrm{Ni} / \mathrm{CeO}_{2}$ sample. On the other hand, the TPR profiles of the $\mathrm{Ni} / \mathrm{CeO}_{2}$ and $\mathrm{Ni}-\mathrm{Cu} / \mathrm{CeO}_{2}$ 
samples showed a sharp reduction peak than the rest of the samples. The sharp peak observed on theses samples corresponds to high uniformity in the Ni crystallite size. TPR profiles of the samples after catalytic reaction showed lower $\mathrm{H}_{2}$ consumption, indicating that under OSRM conditions the active phase is partial oxidized. On $\mathrm{Cu} / \mathrm{CeO}_{2}$ samples was found by EPR technique the presence of the ion $\mathrm{Cu}^{2+}$ forming a nano-sized two-dimensional structure after OSRM reaction [26; 66; 67]. Oguchi et al. [22] observed a reduction peak on the $\mathrm{CuO} / \mathrm{ZrO}_{2}$ sample post-reaction. They concluded that the $\mathrm{Cu}_{2} \mathrm{O}$ catalyst was stabilized during the SRM reaction. Turco et al. [68] suggested that there was a zone within the catalytic bed where the catalyst is oxidized, and another zone where it was reduced. This phenomena could be occurred on our samples, because, generally in oxidative steam reforming process, evidence suggest that the front of the catalyst bed is partially oxidized and the downstream of the catalyst bed remains in the reduced state.

\subsubsection{DRIFTS of CO adsorption}

In situ DRIFT spectra of the monometallic $\mathrm{Ni} / \mathrm{CeO}_{2}$ and $\mathrm{Cu} / \mathrm{CeO}_{2}$ samples and the three bimetallic $\mathrm{Cu} / \mathrm{Ni}$-base samples exposed to a $2.5 \% \mathrm{CO} / \mathrm{He}$ gas mixture recorded at room temperature with the aim to evaluate the influence of the metal addition to $\mathrm{CeO}_{2}$ on the type and amount of different surface species. Fig. 4 shows an infrared spectrum in the 2200-2000 $\mathrm{cm}^{-1}$ regions of the $\mathrm{Cu} / \mathrm{Ni}$-base catalysts. The $\mathrm{CO}$ absorption band was observed at 2130 and $2100 \mathrm{~cm}^{-1}$ on the $\mathrm{Ni} / \mathrm{CeO}_{2}$ and $\mathrm{Cu} / \mathrm{CeO}_{2}$ samples respectively. It is generally acknowledged that carbonyl bands at wavenumbers lower than ca. $2115 \mathrm{~cm}^{-1}$ are due to carbonyl species adsorbed on metallic copper particles [69] while those at higher wavenumber correspond to carbonyls adsorbed on oxidized copper sites, so, the wavenumber increasing with the copper oxidation state. Variations in the frequency of these carbonyls have been related to changes in the nature of the exposed faces (i.e., in the degree of coordination of the copper centers). The main component at $2100 \mathrm{~cm}^{-1}$ was associated to $\mathrm{CO}$ adsorption on $\mathrm{Cu}$ sites of stepped particles (i.e., «110〉 plane) [70]. The band at $2135 \mathrm{~cm}^{-1}$ observed on the bimetallic samples was close to $\mathrm{Ni} / \mathrm{CeO} 2$ catalyst, although it is slightly shifted to higher wavenumbers but it is virtually the same independently of the $\mathrm{Cu}$ and $\mathrm{Ni}$ addition to $\mathrm{CO}_{2}$. In these bimetallic samples the absorption band corresponding to $\mathrm{CO}$ adsorption on $\mathrm{Cu}$ is totally suppressed (Fig. 4b). This finding suggests that the bimetallic samples are richer with $\mathrm{Ni}$ atoms in the surface of the catalysts. On the other hand, the high intensity in the CO-band observed on the bimetallic samples than monometallic catalysts could be associated to major dispersion of the metal active phase on the $\mathrm{CeO}_{2}$. Differences in the $\mathrm{CO}$-chemisorption were observed on the region of $1800-1000 \mathrm{~cm}^{-1}$ (Fig. 4c). CO chemisorption on the reduced surface $\mathrm{CeO}_{2}$ and $\mathrm{Mo} / \mathrm{CeO}_{2}$ samples showed bidentate carbonate (as-1340, s-1680 and as-1320, s-1690 $\mathrm{cm}^{-1}$ ), bicarbonate (1220, s-1460, s-1490 and as- $1630 \mathrm{~cm}^{-1}$ ), and bridged carbonate (as-1285 and $\left.\mathrm{s}-1750 \mathrm{~cm}^{-1}\right)$ [71; 72]. No bands for the carbonate-like species was detected in the region of $1800-1000 \mathrm{~cm}^{-1}$ on the bimetallic samples prepared by successive impregnation as well for $\mathrm{Cu} / \mathrm{CeO}_{2}$ sample which indicates that $\mathrm{CO}$ does not adsorb on these materials. 


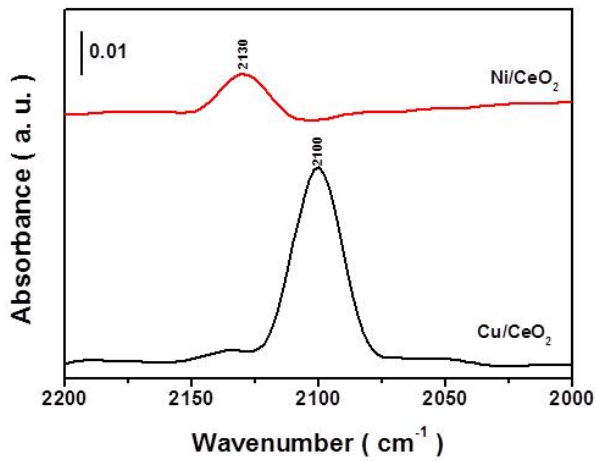

(a)

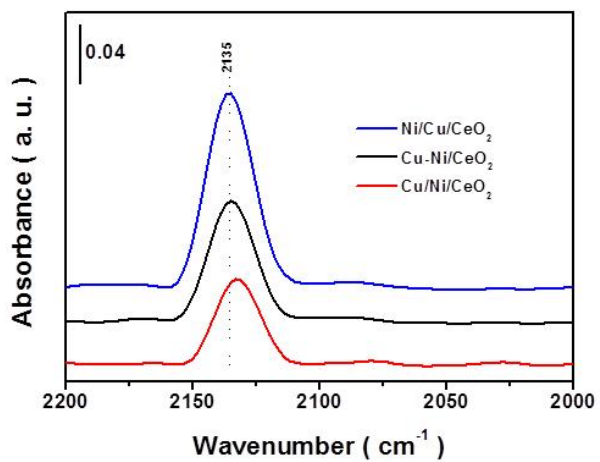

(b)

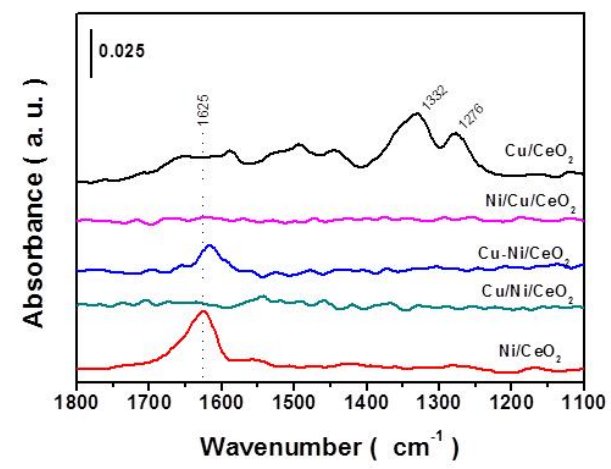

(c)

Figure 4. Diffuse reflectance FTIR spectra of $\mathrm{CO}$ adsorbed on monometallic-a and bimetallic-b catalysts. CO-absorption region of $1800-1000 \mathrm{~cm}^{-1}$ on all samples-c.

\subsubsection{Catalytic activity of the $\mathrm{Cu}-\mathrm{Ni} / \mathrm{CeO}$ 2 catalysts on the OSRM reaction}

The effect of the $\mathrm{Cu}$ and $\mathrm{Ni}$ addition to $\mathrm{CeO}_{2}$ was evaluated on the oxidative steam reforming of methanol (OSRM) reaction from 200 to $400{ }^{\circ} \mathrm{C}$. Fig. 5a-b summarizes the results of the $\mathrm{CH}_{3} \mathrm{OH}$ conversion and $\mathrm{H}_{2}$ selectivity over various catalysts as a function of the reaction temperature. It is clear that the bare- $\mathrm{CeO}_{2}$ showed poor catalytic activity at the maximum reaction temperature. In general in all the samples the methanol conversion increased with an increase in the reaction temperature but, it is different when $\mathrm{Cu}$ and/or $\mathrm{Ni}$ were impregnated to $\mathrm{CeO}_{2}$. At the beginning of the reaction the $\mathrm{Cu} / \mathrm{CeO}_{2}$ catalyst showed better methanol conversion than the other samples. When the temperature was raising at $300{ }^{\circ} \mathrm{C}$ the $\mathrm{Cu} / \mathrm{CeO}_{2}$ and the bimetallic $\mathrm{Cu}-\mathrm{Ni} / \mathrm{CeO}_{2}$ (prepared by co-impregnation) catalysts had the same methanol conversion (40\%). Following by the bimetallic samples prepared by successive impregnation and the worst catalyst for methanol conversion was the $\mathrm{Ni} / \mathrm{CeO}_{2}$ sample. At the maximum reaction temperature the methanol conversion showed the following order: $\mathrm{Ni} / \mathrm{CeO}_{2}>\mathrm{Cu}-\mathrm{Ni} / \mathrm{CeO}_{2}>\mathrm{Ni} / \mathrm{Cu} / \mathrm{CeO}_{2}>\mathrm{Cu} / \mathrm{Ni} / \mathrm{CeO}_{2}>\mathrm{CeO}_{2}$. In previous 
study was observed that when $\mathrm{Ni}$ was supported on $\mathrm{CeO}_{2}$ it showed better methanol conversion than $\mathrm{Ni} / \mathrm{ZrO}_{2}$ sample [38]. López et al. [39] reported that the $\mathrm{Ni} / \mathrm{Cu} / \mathrm{ZrO}{ }_{2}$ and $\mathrm{Cu} / \mathrm{Ni} / \mathrm{ZrO}_{2}$ catalysts prepared by successive impregnation, showed high catalytic activity and $\mathrm{H}_{2}$ selectivity than bimetallic sample prepared by simultaneous impregnation and the monometallic catalysts on the OSRM reaction. They calculated the reactivity of the model catalysts prepared by successive impregnation and observed that the band gap of the bimetallic models decreases, then, an electron transfer mechanism is favored at the interface between the bimetallic structures and the support, facilitating the redox properties of the catalysts, giving a higher OSRM activity [39]. In our case, we observed that the $\mathrm{Ni} / \mathrm{CeO}_{2}$ and $\mathrm{Cu}-\mathrm{Ni} / \mathrm{CeO}_{2}$ (prepared by co-impregnation) samples had the best catalytic activity at the maximum reaction temperature. On these samples was observed by DRIFT technique the CO-band at $1625 \mathrm{~cm}^{-1}$ which was not present on the other samples. This finding can be attributed that the $\mathrm{CO}$ adsorption, in the carbonate species range were not favored on the other catalysts, indicating that $\mathrm{CO}$ does not adsorb on these materials, and so there are some blockade sites for catalytic reaction. The selectivity towards $\mathrm{H}_{2}$ carried out at $200-400{ }^{\circ} \mathrm{C}$ on $\mathrm{Cu}-\mathrm{Ni}$-base catalysts supported on $\mathrm{CeO}_{2}$ catalysts increased progressively by increasing the reaction temperature. It is clear that the $\mathrm{Ni} / \mathrm{CeO}_{2}$ and $\mathrm{Cu}-\mathrm{Ni} / \mathrm{CeO}_{2}$ catalysts showed higher selectivity toward $\mathrm{H}_{2}$ than the others samples.

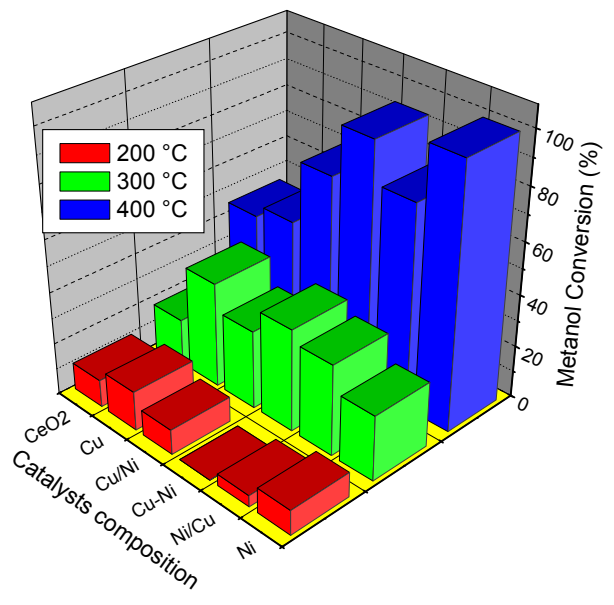

(a)

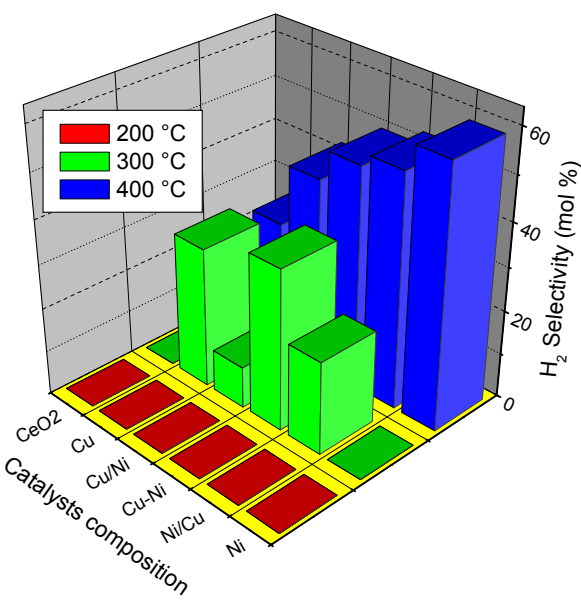

(b)

Figure 5. Methanol conversion of the $\mathrm{Ni} / \mathrm{Cu}$ supported on $\mathrm{CeO}_{2}-(\mathrm{a})$ and $\mathrm{H}_{2}$ selectivity-(b)

\section{2. $\mathrm{Au} / \mathrm{CeO}_{2}$ system}

\subsubsection{Experimental section}

$\mathrm{CeO}_{2}$ catalyst was prepared in advance by precipitation method. $\mathrm{NH}_{4} \mathrm{OH}$ (Baker) was added drop wise to an aqueous solution of $\left(\mathrm{Ce}\left(\mathrm{NO}_{3}\right)_{3} \bullet 6 \mathrm{H}_{2} \mathrm{O}\right)$. The precipitated solid was 
aged for $24 \mathrm{~h}$ and the residual liquid was removed by decanting, then the solid was dried at $100{ }^{\circ} \mathrm{C}$ for $24 \mathrm{~h}$. The solid material was calcined at $100{ }^{\circ} \mathrm{C} 1 \mathrm{~h}$ under an air stream and then at $500{ }^{\circ} \mathrm{C}$ for $5 \mathrm{~h}$. The prepared support was impregnated with an aqueous solution of $\mathrm{HAuCl}_{4}$ at an appropriate concentration to yield 1 and 3 wt $\%$ of total $\mathrm{Au}$ in the catalysts. The samples were dried at $100^{\circ} \mathrm{C}$ for $1 \mathrm{~h}$ and then calcined at $400{ }^{\circ} \mathrm{C}$ for $2 \mathrm{~h}$ in static air and finally reduced with a $\mathrm{H}_{2}(5 \%) / \mathrm{He}$ stream at $350{ }^{\circ} \mathrm{C} 1 \mathrm{~h}$ before the characterization and activity test. The labeling of different catalysts will be referred as follows: $\mathrm{nAu} / \mathrm{CeO}_{2}$ where $\mathrm{n}=1$ and 3 wt. \% of $\mathrm{Au}$ in the catalyst respectively. The steadystate activity in the SRM reaction was performed in a conventional fixed-bed flow reactor (8 mm i.d.) using $0.1 \mathrm{~g}$ of the catalyst in a temperature range from 300 to $475^{\circ} \mathrm{C}$ with steps of $25^{\circ} \mathrm{C}$ with $6 \mathrm{~h}$ of stabilization time at each temperature and atmospheric pressure on an automatic multitask unit RIG-100 from ISR INC. The catalyst was first activated in a stream of $\mathrm{H}_{2}(60 \mathrm{~mL} / \mathrm{min})$ from room temperature to $350{ }^{\circ} \mathrm{C}$ with a heating rate of $10^{\circ} \mathrm{C} / \mathrm{min}$ and held at this temperature for $1 \mathrm{~h}$. A thermocouple in contact with the catalytic bed allowed the control of the temperature inside the catalyst was used. The sample was brought up to the reaction temperature in He and the reaction mixture was introduced. For the SRM reaction, He $\left(60 \mathrm{~mL} / \mathrm{min}, \mathrm{GHSV}=30,000 \mathrm{~h}^{-1}\right.$ based on the total flow) was added by means of a mass flow controller (RIG-100) and bubbled through a tank containing mixture of water and methanol, the partial pressure of $\mathrm{CH}_{3} \mathrm{OH}$ and $\mathrm{H}_{2} \mathrm{O}$ was 9999.18 and $1699.86 \mathrm{~Pa}$ respectively. The molar ratio in the steam was $\mathrm{CH}_{3} \mathrm{OH}$ $(1.95 \mu \mathrm{mol}) / \mathrm{H}_{2} \mathrm{O}(1.97 \mu \mathrm{mol})=\mathrm{R} \approx 1.0$ and the other concentration tested was $\mathrm{CH}_{3} \mathrm{OH}(4.7$ $\mu \mathrm{mol}) / \mathrm{H}_{2} \mathrm{O}(1.97 \mu \mathrm{mol})=\mathrm{R} \approx 2.4$. The effluent gas of the reactor was analyzed by gaschromatography (Gow-Mac 580 instrument) equipped with a two columns system (molecular sieve $5 \AA$ and Porapack Q columns), double injector controlled by Clarity software V.2.6.04.402 and TCD. The first column was used to separate the gaseous products such as $\mathrm{H}_{2}, \mathrm{O}_{2}, \mathrm{CH}_{4}$ and $\mathrm{CO}$. The second column was used to separate water, methanol, methyl formate (MF) and $\mathrm{CO}_{2}$. The $\mathrm{GC}$ analysis was performed in isothermal conditions (oven temperature $=100{ }^{\circ} \mathrm{C}$ ). The equations used to determine the methanol conversion and selectivity was showed above.

\section{Results and discussion}

BET surface area calculated by the $\mathrm{N}_{2}$ adsorption-desorption through the single point method of the $1 \mathrm{Au} / \mathrm{CeO}_{2}$ and $3 \mathrm{Au} / \mathrm{CeO}_{2}$ catalysts after thermal pretreatments were 44 and $34 \mathrm{~m}^{2} / \mathrm{g}$ respectively. Figure $6(\mathrm{a}, \mathrm{b})$ showed a representative area of the $1 \mathrm{Au} / \mathrm{CeO} 2$ and $3 \mathrm{Au} / \mathrm{CeO}_{2}$ catalysts respectively. It showed that both samples are constituted by white spots identified as $\mathrm{Au}$ on large $\mathrm{CeO}_{2}$ particles. Among these catalysts the sample with high $\mathrm{Au}$ loading showed big $\mathrm{Au}$ nanoparticles (large white spots) than on the $1 \mathrm{Au} / \mathrm{CeO}_{2}$ catalyst. Inset image in Figure 6a, showed an amplification of $\mathrm{CeO}_{2}$ support using FE-SEM technique. Under this analysis we found that the $\mathrm{CeO}_{2}$ is constituted by nanoparticles with diameters $20 \mathrm{~nm}$. 


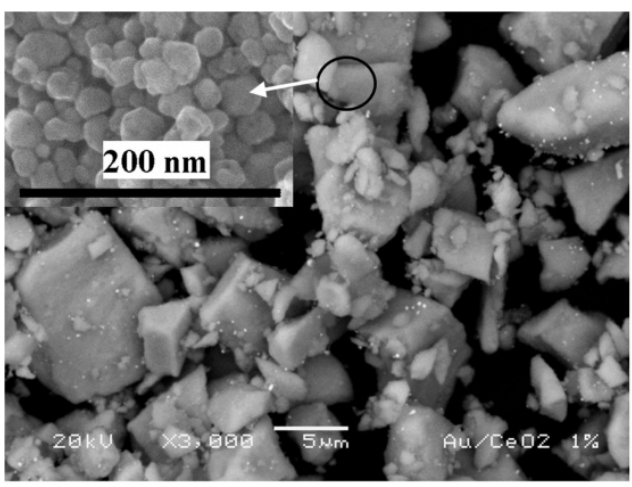

(a)

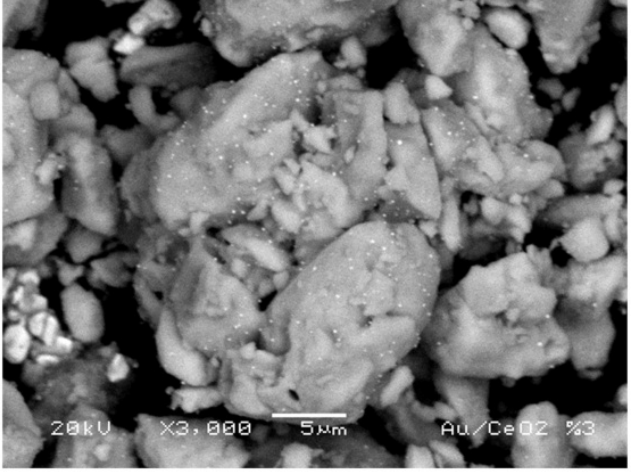

(b)

Figure 6. SEM image of: (a) $1 \mathrm{Au} / \mathrm{CeO}_{2}$ catalyst. Inset image corresponds to $\mathrm{CeO}_{2}$ support obtained by FE-SEM. (b) $3 \mathrm{Au} / \mathrm{CeO}_{2}$ catalyst.

Figure 7 showed the XRD patterns of the $1 \mathrm{Au} / \mathrm{CeO}_{2}$ and $3 \mathrm{Au} / \mathrm{CeO}_{2}$ catalysts. It is possible to observe on the XRD pattern; characteristic peaks of the metallic gold and the others corresponding to the fluorite structure of ceria $\left(\mathrm{CeO}_{2}\right.$-cerianite). In addition, it is clear that the intensity of the diffraction peaks of the $\mathrm{Au}^{0}$ increases proportionally as the $\mathrm{Au}$ was loading on $\mathrm{CeO}_{2}$ suggesting on this sample a big Au crystallite size. The diffraction patterns of the $\mathrm{Au} / \mathrm{CeO}_{2}$ samples showed considerable line widths and no overlapping $\mathrm{Au}$ and $\mathrm{CeO}_{2}$ diffraction peaks. We use the peaks display in the 35-45 = $2 \theta$ range to estimate the average $\mathrm{Au}$ crystallite size. The average value of the $\mathrm{CeO}_{2}$ and the $\mathrm{Au}$ metal crystallite sizes on $1 \mathrm{Au} / \mathrm{CeO}_{2}$ and $3 \mathrm{Au} / \mathrm{CeO}_{2}$ samples were determined by Scherrer equation and it corresponds to 19,23 and $33 \mathrm{~nm}$ respectively.

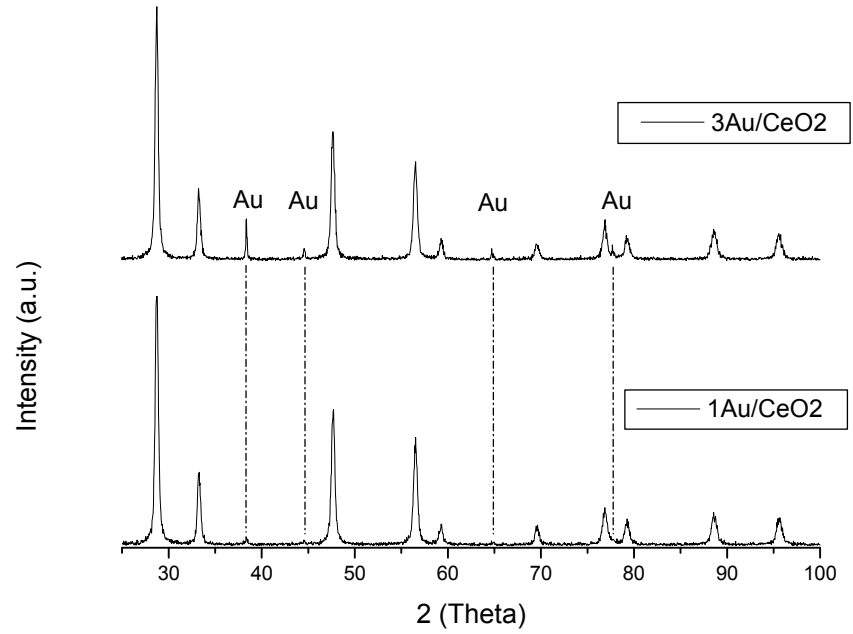

Figure 7. $\mathrm{X}$ ray diffraction patterns of the $1 \mathrm{Au} / \mathrm{CeO}_{2}$ and $3 \mathrm{Au} / \mathrm{CeO}_{2}$ catalysts. Cubic structure $\mathrm{CeO}_{2}$ (fluorite structure) and characteristic peaks of the metallic gold. 
TEM analysis of the $1 \mathrm{Au} / \mathrm{CeO}_{2}$ catalyst is showed on Figure $8 \mathrm{a}$; it is possible to observe the homogeneous distribution of the $\mathrm{CeO}_{2}$ particles about $20 \mathrm{~nm}$ of diameter. This value is close to the FE-SEM observation and the results calculated by Scherrer equation. High resolution image of $\mathrm{Au}$ nanoparticle (Figure $8 \mathrm{~b}$ ) revealed that after thermal treatments, the $\mathrm{Au}$ nanoparticle generally had a hemi-spherical shape. The Au particle size measure was $\sim 17$ $\mathrm{nm}$. Analysis of the electron diffraction patterns of the Au nanostructures, inset on Figure $8 \mathrm{~b}$, show that the crystalline structure grows as a gold fcc single crystal. These Au nanoparticles was recorded along [110] orientation. Figure 8c showed the TEM image of the $3 \mathrm{Au} / \mathrm{CeO}_{2}$ catalyst, inset image on Figure $8 \mathrm{c}$, showed the EDS spectra of the $\mathrm{CeO}_{2}$ support and a gold nanoparticle the last one about $30 \mathrm{~nm}$ of diameter.

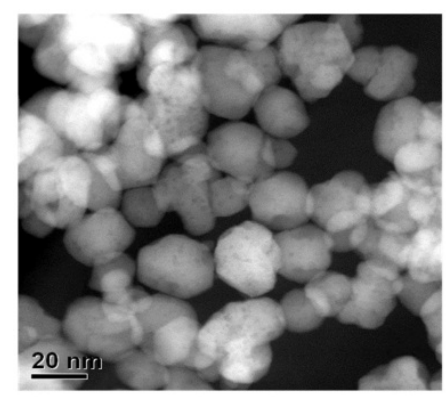

(a)

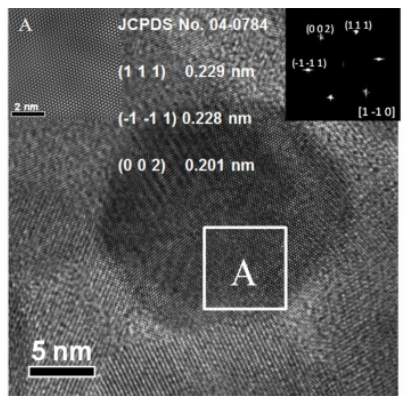

(b)

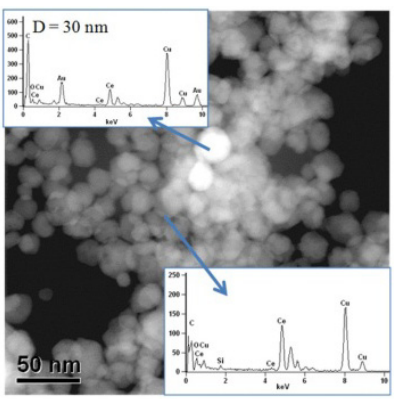

(c)

Figure 8. a) Low magnification TEM images of the $1 \mathrm{Au} / \mathrm{CeO}_{2}$ catalyst. b) HRTEM image of the $\mathrm{Au}$ nanoparticle from $1 \mathrm{Au} / \mathrm{CeO}_{2}$ catalyst which was recorded along [110] orientation. The d-spacing measured is showed inset image. The particle size was about $17 \mathrm{~nm}$. c) Low magnification TEM images of the $3 \mathrm{Au} / \mathrm{CeO}_{2}$ image. Inset images showed the EDS spectra of the Au nanoparticle about $30 \mathrm{~nm}$ of diameter and $\mathrm{CeO}_{2}$ support.

The TPR profiles of the Au-base catalysts deposited on $\mathrm{CeO}_{2}$ are depicted in Figure 9. This technique was also employed to found the optimal reduction temperature in the catalysts. TPR profiles showed differences in the hydrogen consumption depending of the gold content. Reduction of $\mathrm{Au} / \mathrm{CeO}_{2}$ samples were observed from 150 to $330{ }^{\circ} \mathrm{C}$. For this reason, the catalysts were first activated in $\mathrm{H}_{2}$ stream at $350{ }^{\circ} \mathrm{C}$ before all the characterization. As reported in literature, pure $\mathrm{CeO}_{2}$ showed two reduction peaks at about 500 and $800{ }^{\circ} \mathrm{C}$, and were interpreted as the reduction of surface capping oxygen and bulk phase lattice oxygen, respectively [26; 73]. For $\mathrm{Au} / \mathrm{CeO}_{2}$ catalysts, the peak assigned to ceria surface layer reduction was reported from 120 to $178{ }^{\circ} \mathrm{C}$ [54; 74]. In our calcined $1 \mathrm{Au} / \mathrm{CeO}_{2}$ catalyst, the hydrogen consumption peaks were observed within temperature range $175-325{ }^{\circ} \mathrm{C}$, which could be deconvoluted into three components at reduction temperatures of 215, 257 and 294 ${ }^{\circ} \mathrm{C}$ respectively. Whereas, the calcined $3 \mathrm{Au} / \mathrm{CeO}_{2}$ catalyst exhibited a broad reduction peak, which could be decompounds into three components at reduction temperatures of 184, 267 and $297^{\circ} \mathrm{C}$. It is clear that the intensity of the peak at $257{ }^{\circ} \mathrm{C}$ observed on the $1 \mathrm{Au} / \mathrm{CeO}_{2}$ sample diminish significantly, and was shifted to the high-temperature region when the amount of $\mathrm{Au}$ was increased, because, the large crystallites tend to be reduced slower than 
the small ones due to their relatively lower surface area exposed to $\mathrm{H}_{2}$. Rodriguez et al. Showed by XAFS that Au facilitates the oxide reduction of the matrix respect to pure ceria [75]. Andreeva et al. [52] observed by TPR technique two reducible species on $\mathrm{Au}-\mathrm{CeO}_{2}$ samples. The low-temperature peak on the TPR profile was connected with the reduction of the oxygen species on the fine gold particles, and the high-temperature peak was due to the reduction of the surface ceria. Taking into account these results and the differences in the gold loading in our samples, we assume that the former peak corresponds to the reduction of Au oxide nanoparticles, then it causes spill-over of hydrogen onto the support inducing a concurrent reduction of both the $\mathrm{Au}$ oxide and the surface of $\mathrm{CeO}_{2}$ as was reported on other Ce-base catalysts $[26 ; 28 ; 52]$.

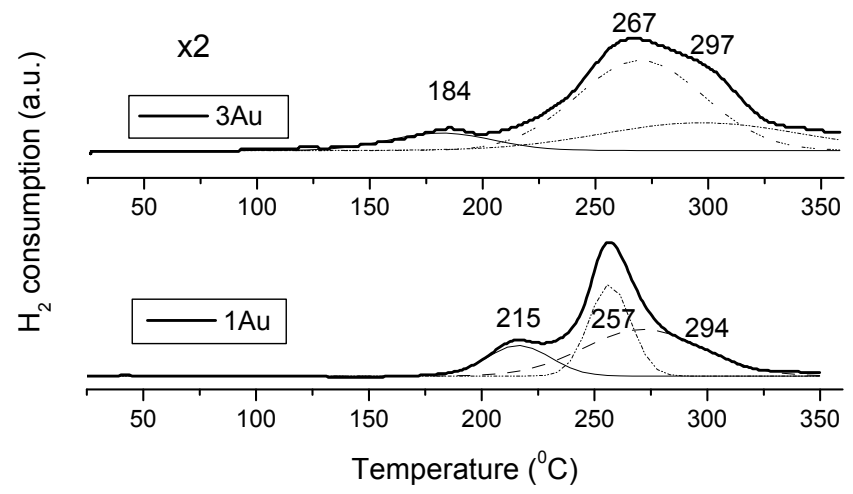

Figure 9. TPR profiles of the fresh $\mathrm{Au} / \mathrm{CeO}_{2}$ catalysts calcined at $400{ }^{\circ} \mathrm{C}$.

The catalytic activity of the $\mathrm{Au} / \mathrm{CeO}_{2}$ catalysts as a function of the reaction temperature on the steam reforming of methanol reaction is presented on Figure 10. The light-off temperature of both samples started at $\sim 350{ }^{\circ} \mathrm{C}$ at the molar $\mathrm{CH}_{3} \mathrm{OH} / \mathrm{H}_{2} \mathrm{O}=2.4$ ratio, and the activity increased as temperature was rising. At the maximum reaction temperature, the methanol conversion observed on the $1 \mathrm{Au} / \mathrm{CeO}_{2}$ and $3 \mathrm{Au} / \mathrm{CeO}_{2}$ catalysts was 95 and $90 \%$ respectively. The better catalytic activity observed on the $1 \mathrm{Au} / \mathrm{CeO}_{2}$ sample than on the $3 \mathrm{Au} / \mathrm{CeO}_{2}$ catalyst, could be attributed to differences in the Au particle size how was observed by XRD, SEM and TEM analysis. So, on the $3 \mathrm{Au} / \mathrm{CeO}_{2}$ catalyst the $\mathrm{Au}$ particle size was bigger than on the $1 \mathrm{Au} / \mathrm{CeO}_{2}$ catalyst. Croy et al. [76] studied the $\mathrm{H}_{2}$ production through methanol decomposition on $\mathrm{Pt} / \mathrm{TiO}_{2}$ catalysts. They observed high catalytic activity on the catalysts with small particle size and diminish as the particle size increase. On methane combustion was observed better catalytic activity on the catalyst with low gold loading than the one with high gold loading, this result was associated with the dispersion of $\mathrm{Au}$ and the atomic ratio of $\mathrm{Au}^{3+} / \mathrm{Au}^{0}$ [77; 78]. However, Guzman and Gates [79] not found evidence between the $\mathrm{Au}$ cluster size and the catalytic activity on $\mathrm{Au} / \mathrm{MgO}$ catalyst during the $\mathrm{CO}$ oxidation reaction with EXAFS technique. Wang et al. [80] suggested that the active sites in Au-ceria catalysts for the WGS probably contain Au nanoparticles and partially reduced ceria. It has been suggested that the presence of gold clusters weakens the bonding of the oxygen species on $\mathrm{CeO}_{2}$ and facilitates the formation of more reactive species [53; 80;81]. 


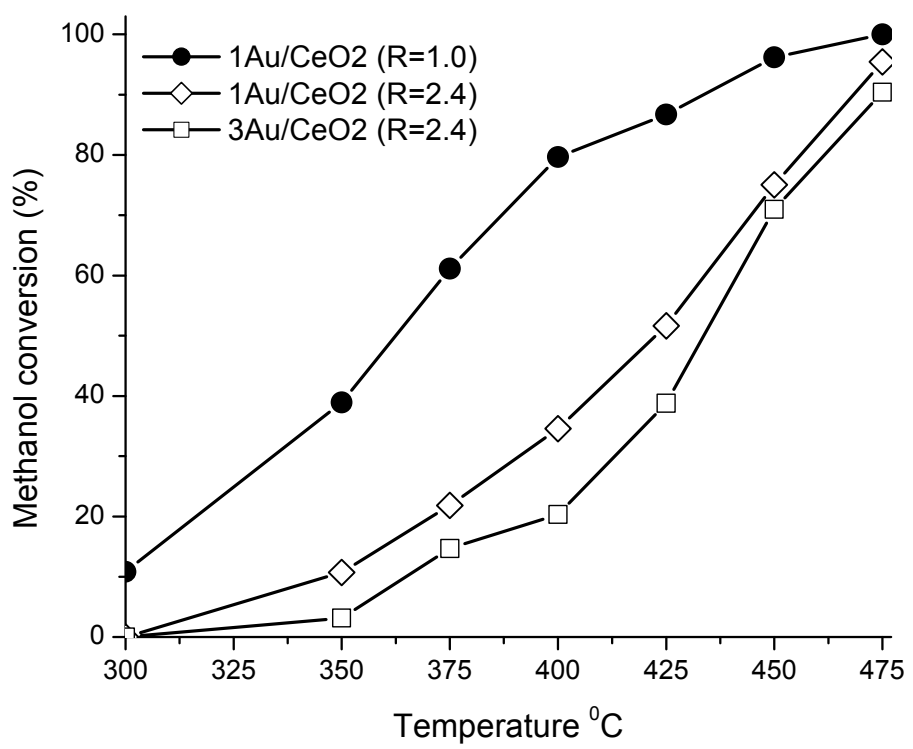

Figure 10. Temperature dependence of SRM activity of $\mathrm{Au} / \mathrm{CeO}_{2}$ catalysts. Partial pressure of $\mathrm{CH}_{3} \mathrm{OH}$ and $\mathrm{H}_{2} \mathrm{O}$ was 9999.18 and 1699.86 Pa respectively. GHVS=30,000 $\mathrm{h}^{-1}$. The molar ratio in the steam was $\mathrm{CH}_{3} \mathrm{OH}(1.95 \mu \mathrm{mol}) / \mathrm{H}_{2} \mathrm{O}(1.97 \mu \mathrm{mol})=\mathrm{R} \approx 1.0$ and $\mathrm{CH}_{3} \mathrm{OH}(4.7 \mu \mathrm{mol}) / \mathrm{H}_{2} \mathrm{O}(1.97 \mu \mathrm{mol})=\mathrm{R} \approx 2.4$.

The effect of the molar $\mathrm{CH}_{3} \mathrm{OH} / \mathrm{H}_{2} \mathrm{O}$ ratio was evaluated on the $1 \mathrm{Au} / \mathrm{CeO}_{2}$ catalyst and presented on Figure 10. It showed clearly that this sample had better catalytic activity when the molar $\mathrm{CH}_{3} \mathrm{OH} / \mathrm{H}_{2} \mathrm{O}$ ratio is close to $\mathrm{R}=1$ than on the $\mathrm{R}=2.4$. At the beginning of the reaction $\left(300{ }^{\circ} \mathrm{C}\right)$ the conversion of methanol was $11 \%$ and, increase when the temperature was rising. At $375{ }^{\circ} \mathrm{C}$ the catalyst reached near $61 \%$ conversion whereas on the $\mathrm{R}=2.4$ ratio the methanol conversion only reached $\sim 22 \%$. This effect is caused by the modification on the feed concentrations of the fuel as was reported on [82]. The methanol conversion observed at the maximum reaction temperature, reached almost $100 \%$ on the molar $\mathrm{CH}_{3} \mathrm{OH} / \mathrm{H}_{2} \mathrm{O}$ ratio $\mathrm{R}=1$, while on the $\mathrm{R}=2.4$ ratio only $95 \%$ conversion was observed. This finding suggests that the methanol is adsorbed preferable on the surface of the catalysts than water. Table 2 showed the catalytic performance on steam reforming of methanol reaction from 300 to $475{ }^{\circ} \mathrm{C}$ range of the bare $\mathrm{CeO}_{2}$ and $1 \mathrm{Au} / \mathrm{CeO}_{2}$ catalyst using the molar $\mathrm{CH}_{3} \mathrm{OH} / \mathrm{H}_{2} \mathrm{O}$ ratio $\mathrm{R}=1$. As it can be seen, $\mathrm{CeO}_{2}$ support showed low catalytic activity in almost all temperature range. However, at the end of the reaction the methanol conversion is almost $100 \%$ for these samples. This finding showed the effect of the gold nanoparticles on $\mathrm{CeO}_{2}$ during the catalytic activity. Gazsi et al. [83] suggested a cooperative effect between $\mathrm{Au}$ nanoparticles and $\mathrm{CeO}_{2}$ support on the decomposition and reforming of methanol as was reported for other catalysts $[9 ; 26 ; 64 ; 84]$. 


\begin{tabular}{c|cccccccccc}
\hline \multirow{2}{*}{$\begin{array}{c}\text { Temperature } \\
\left({ }^{\circ} \mathrm{C}\right)\end{array}$} & \multicolumn{5}{|c|}{$\begin{array}{c}\mathrm{CeO}_{2} \\
\text { Methanol conversion and selectivity } \\
(\%)\end{array}$} & \multicolumn{5}{c}{$\begin{array}{c}\text { Methanol conversion and selectivity } \\
(\%)\end{array}$} \\
\cline { 2 - 12 } & Conv. & $\mathrm{H}_{2}$ & $\mathrm{CH}_{4}$ & $\mathrm{CO}$ & $\mathrm{CO}_{2}$ & Conv. & $\mathrm{H}_{2}$ & $\mathrm{CH}_{4}$ & $\mathrm{CO}$ & $\mathrm{CO}_{2}$ \\
\hline 300 & 9.2 & 0 & 0 & 41.5 & 58.5 & 10.8 & 51.6 & 0 & $\mathrm{O}$ & 48.4 \\
350 & 8.7 & 0 & 0 & 71.4 & 28.6 & 39.0 & 52.4 & 0.8 & 0.1 & 46.7 \\
400 & 18.2 & 74.8 & 7.4 & 14.2 & 3.5 & 79.7 & 81.5 & 1.7 & 3.0 & 13.8 \\
425 & 43.5 & 60.7 & 13.1 & 21.8 & 4.4 & 86.7 & 86.5 & 2.3 & 7.1 & 4.1 \\
450 & 83.6 & 54.7 & 13.0 & 27.4 & 4.9 & 96.2 & 84.4 & 3.0 & 10.5 & 2.1 \\
475 & 100 & 58.2 & 7.5 & 28.6 & 5.7 & 100 & 84.4 & 3.1 & 10.6 & 1.9 \\
\hline
\end{tabular}

Table 2. Catalytic activity of the bare $\mathrm{CeO}_{2}$ and $1 \mathrm{Au} / \mathrm{CeO}_{2}$ catalyst. The molar ratio in the steam was $\mathrm{CH}_{3} \mathrm{OH}(1.95 \mu \mathrm{mol}) / \mathrm{H}_{2} \mathrm{O}(1.97 \mu \mathrm{mol})=\mathrm{R} \approx 1.0$

The reaction products observed on the steam reforming of methanol reaction of the $\mathrm{Au} / \mathrm{CeO}_{2}$ catalysts were $\mathrm{H}_{2}, \mathrm{CO}, \mathrm{CO}_{2}, \mathrm{CH}_{4}$ and $\mathrm{H}_{2} \mathrm{O}$. Small production of methyl formate as by-product of the reaction was observed in both samples. Figure 11a showed the distribution of hydrogen on the Au-base catalysts. Higher $\mathrm{H}_{2}$ production was observed from 300 to $400{ }^{\circ} \mathrm{C}$ range on the catalysts tested with high molar $\mathrm{CH}_{3} \mathrm{OH} / \mathrm{H}_{2} \mathrm{O}$ ratio $\mathrm{R}=2.4$ than $\mathrm{R}=1$. The drop of the hydrogen selectivity at higher temperatures could be attributed at the formation of $\mathrm{CH}_{4}$. At the beginning of the reaction all samples showed low $\mathrm{CO}$ selectivity, Figure 11b. However, as the reaction temperature raise from 375 to $470{ }^{\circ} \mathrm{C}$, the $\mathrm{CO}$ production increase and the selectivity toward $\mathrm{CO}_{2}$ decrease. It is clear from Figure $11 \mathrm{~b}$ that the $3 \mathrm{Au} / \mathrm{CeO}_{2}$ sample showed high selectivity toward $\mathrm{CO}$ than on the $1 \mathrm{AuCeO}_{2}$ sample. In addition, we observed that the $\mathrm{CO}$ production is practically the same on the $1 \mathrm{AuCeO}_{2}$ catalyst $(\sim 10 \%)$ independently of the molar $\mathrm{CH}_{3} \mathrm{OH} / \mathrm{H}_{2} \mathrm{O}$ ratio. Table 2 showed the selectivity of the bare $\mathrm{CeO}_{2}$ compared with $1 \mathrm{Au} / \mathrm{CeO}_{2}$ catalyst. It showed the beneficial effect of the gold nanoparticles on the $\mathrm{CeO}_{2}$. Because, the selectivity toward undesirable by-products such as $\mathrm{CO}$ and $\mathrm{CH}_{4}$ observed on the bare $\mathrm{CeO}_{2}$, were drop on the $1 \mathrm{Au} / \mathrm{CeO}_{2}$ catalyst and the selectivity toward $\mathrm{H}_{2}$ was improved on this catalyst.

Time on-stream studies (Fig. 12) at $350{ }^{\circ} \mathrm{C}$ in the $1 \mathrm{Au} / \mathrm{CeO}_{2}$ sample with $\mathrm{CH}_{3} \mathrm{OH} / \mathrm{H}_{2} \mathrm{O}$ ratio $=$ 1.0, reveal high stability on the activity during the steam reforming of methanol reaction during a $65 \mathrm{~h}$ of reaction period, as well as high stability in the reaction products. The stability of catalysts under operating conditions is desirable for commercial applications. Fu et al. [73] found no significant change in activity after $120 \mathrm{~h}$ on stream on WGS. This behavior could be suggested that the catalyst maintains the same catalytic species during the SRM reaction and it does not lose by effect of the reaction conditions. So, these results showed that the $\mathrm{CeO}_{2}$ matrix could be use to prevent the vanished of active phase during the reaction. Thus, a cooperative redox mechanism for the SRM reaction on Au-ceria is possible, similar to $\mathrm{Cu}$-ceria or another kind of catalysts $[26 ; 37 ; 63 ; 64 ; 73 ; 85]$ and for the WGS reaction [73]. 


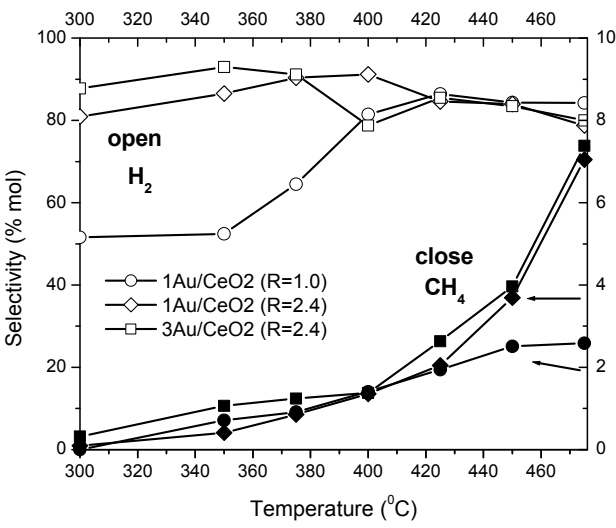

(a)

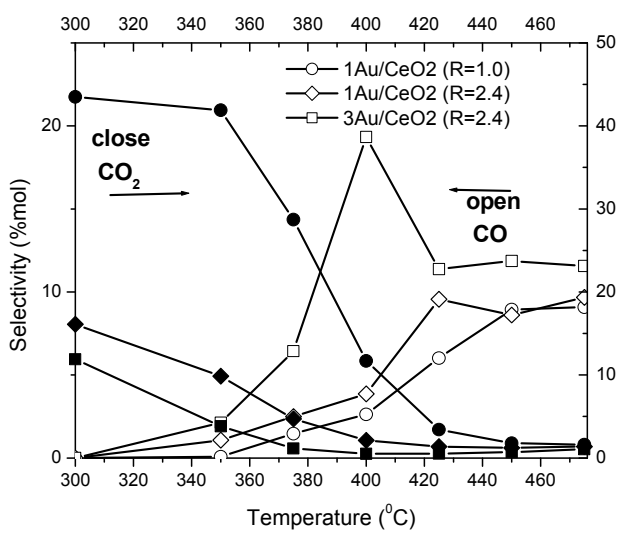

(b)

Figure 11. a) $\mathrm{H}_{2}$ and $\mathrm{CH}_{4}$ selectivity as a function of reaction temperature. b) $\mathrm{CO}$ and $\mathrm{CO}_{2}$ selectivity as a function of reaction temperature. Partial pressure of $\mathrm{CH}_{3} \mathrm{OH}$ and $\mathrm{H}_{2} \mathrm{O}$ was 9999.18 and $1699.86 \mathrm{~Pa}$ respectively. GHVS $=30,000 \mathrm{~h}^{-1}$. The molar ratio in the steam was $\mathrm{CH}_{3} \mathrm{OH}(1.95 \mu \mathrm{mol}) / \mathrm{H}_{2} \mathrm{O}(1.97 \mu \mathrm{mol})=$ $\mathrm{R} \approx 1.0$ and $\mathrm{CH}_{3} \mathrm{OH}(4.7 \mu \mathrm{mol}) / \mathrm{H} 2 \mathrm{O}(1.97 \mu \mathrm{mol})=\mathrm{R} \approx 2.4$.

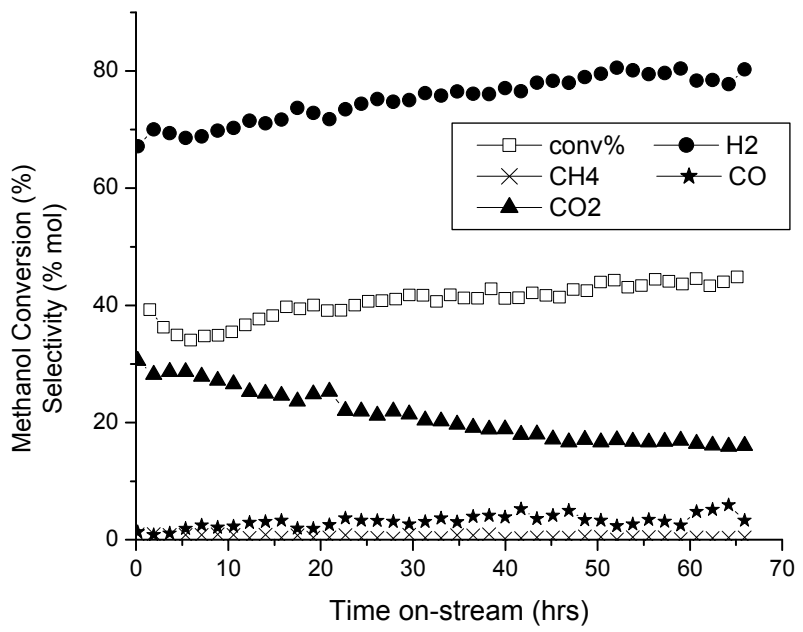

Figure 12. Stability of $1 \mathrm{Au} / \mathrm{CeO}_{2}$ catalyst at $350^{\circ} \mathrm{C}$. Partial pressure of $\mathrm{CH}_{3} \mathrm{OH}$ and $\mathrm{H}_{2} \mathrm{O}$ was 9999.18 and $1699.86 \mathrm{~Pa}$ respectively. GHVS $=30,000 \mathrm{~h}^{-1}$. The molar ratio in the steam was $\mathrm{CH}_{3} \mathrm{OH}(1.95 \mu \mathrm{mol}) / \mathrm{H}_{2} \mathrm{O}$ $(1.97 \mu \mathrm{mol})=\mathrm{R} \approx 1.0$

\section{Conclusion}

$\mathrm{Cu} / \mathrm{CeO}_{2}, \mathrm{Ni} / \mathrm{CeO}_{2}$ and three bimetallic copper-nickel catalysts supported on $\mathrm{CeO}_{2}$ were prepared by the impregnation method and tested in the OSRM reaction. The monometallic $\mathrm{Ni} / \mathrm{CeO}_{2}$ and the bimetallic $\mathrm{Cu}-\mathrm{Ni} / \mathrm{CeO}_{2}$ (synthesized by co-impregnation) catalysts demonstrate both a higher catalytic activity in the OSRM reaction than the other catalysts. CO- 
chemisorption followed by DRIFT technique showed differences in the former samples. So, in the $\mathrm{Ni} / \mathrm{CeO}_{2}$ and $\mathrm{Cu}-\mathrm{Ni} / \mathrm{CeO}_{2}$ catalysts was observed a band at $1625 \mathrm{~cm}^{-1}$ that was not present on the bimetallic samples prepared by successive impregnation as well for the $\mathrm{Cu} / \mathrm{CeO}_{2}$ samples which indicates that $\mathrm{CO}$ does not adsorb on these materials. This suggests that the metal active phase blockage some sites on the support or the active phase, modifies the surface of the catalyst for the adsorption of methanol and water inhibited the catalytic reaction on this system. In the case of the $\mathrm{Au} / \mathrm{CeO}_{2}$ system, nanosized ceria was prepared in advance with particle size of $19 \mathrm{~nm}$ and used as a support for gold nanoparticles. The average Au crystallite size in the $1 \mathrm{Au} / \mathrm{CeO}_{2}$ and $3 \mathrm{Au} / \mathrm{CeO}_{2}$ catalysts was 21 and $31 \mathrm{~nm}$ respectively. Differences in the reducibility of the $\mathrm{Au} / \mathrm{CeO}_{2}$ catalysts were observed depending of the Au loading. $\mathrm{H}_{2}-\mathrm{TPR}$ results showed a shift of the reduction peaks toward high-temperature when the amount of $\mathrm{Au}$ was increased associated with the Au particle size present on the catalysts. The gold-base catalysts supported on $\mathrm{CeO}_{2}$ showed catalytic activity on the SRM reaction and high selectivity toward $\mathrm{H}_{2}$. Among these catalysts the sample with small Au particle size showed best performance in methanol conversion than on the catalyst with big Au particle size. These finding show the relationship between the $\mathrm{Au}$ particle size and the catalytic activity. In addition, it was demonstrate the beneficial effect of gold nanoparticles on the catalytic activity, as well as on the selectivity toward undesirable by-products such as $\mathrm{CO}$ and $\mathrm{CH}_{4}$ and the selectivity toward $\mathrm{H}_{2}$. The stability of the $1 \mathrm{Au} / \mathrm{CeO}_{2}$ catalyst at $350{ }^{\circ} \mathrm{C}$ was followed as a function of time on stream. This result showed high stability during the reaction. It is assumed that the interface between $\mathrm{Au}$ and partially reduced ceria is responsible for the high activity of $\mathrm{Au} / \mathrm{CeO}_{2}$ catalyst. In general we observed different behavior in the catalytic activity in our catalysts in the OSRM reaction to those reported in the literature. This difference could be attributed to the nature of the metal active phase and metal addition to the support. In this way, we suggest that the OSRM reaction could be a structure sensitive reaction according with the literature. However, further work is needed to refine and optimize the catalysts to improve the methanol conversion to produce $\mathrm{CO}$-free hydrogen from the reaction under study.

\section{Author details}

Raúl Pérez-Hernández*, Demetrio Mendoza-Anaya and Albina Gutiérrez Martínez Instituto Nacional de Investigaciones Nucleares, Carr. México-Toluca S/N La Marquesa, Ocoyoacac, México

Antonio Gómez-Cortés Instituto de Física-Universidad Nacional Autónoma de México, D.F., México

\section{Acknowledgement}

Thanks to C. Salinas for technical support and to the projects ININ-CA-009 and CONACYT CB-2008-01-104540 for financial support. Authors would like to acknowledge Dr. Carlos Ángeles for its valuable comments and suggestions on the manuscript.

\footnotetext{
${ }^{*}$ Corresponding Author
} 


\section{References}

[1] Armor, J. N. (1999) The multiple roles for catalysis in the production of H2. Appl. Catal. A: Gen. 159-176: 159.

[2] Peña, M. A., J. P. Gómez, and J. L. G. Fierro (1996) New catalytic routes for syngas and hydrogen production. Appl. Catal. A: Gen. 144: 7-57.

[3] Pakulska, M. M., C. M. Grgicak, and J. B. Giorgi (2007) The effect of metal and support particle size on $\mathrm{NiO} / \mathrm{CeO}_{2}$ and $\mathrm{NiO} / \mathrm{ZrO}_{2}$ catalyst activity in complete methane oxidation. Appl Catal A: Gen. 332: 124-129.

[4] Sprung, C., B. Arstad, and U. Olsbye (2011) Methane Steam Reforming Over $\mathrm{Ni} / \mathrm{NiAl}_{2} \mathrm{O}_{4}$ Catalyst: The Effect of Steam-to-Methane Ratio. Top Catal 54: 1063-1069.

[5] Montoya, J. A., E. Romero-Pascual, C. Gimon, P. D. Angel, and A. Monzón (2000) Methane reforming with $\mathrm{CO}_{2}$ over $\mathrm{Ni} / \mathrm{ZrO}_{2}-\mathrm{CeO}_{2}$ catalysts prepared by sol-gel. Catal Today. 63: 71-85.

[6] Roh, H.-S., K.-W. Jun, W.-S. Dong, J.-S. Chang, S.-E. Park, and Y.-I. Joe (2002) Highly active and stable $\mathrm{Ni} / \mathrm{Ce}-\mathrm{ZrO} 2$ catalyst for $\mathrm{H} 2$ production from methane. J. Mol Catal A: Chemical. 181: 137-142.

[7] Takeguchi, T., S.-n. Furukawa, and M. Inoue (2001) Hydrogen Spillover from $\mathrm{NiO}$ to the Large Surface Area $\mathrm{CeO}_{2}-\mathrm{ZrO}_{2}$ Solid Solutions and Activity of the $\mathrm{NiO} / \mathrm{CeO}_{2}-\mathrm{ZrO}_{2}$ Catalysts for Partial Oxidation of Methane. J. Catal. 202: 14-24.

[8] Matsumura, Y., and T. Nakamori (2004) Steam Reforming of Methane over Nickel Catalysts. Appl. Catal. A: Gen. 258: 107-114.

[9] Agrell, J., H. Birgersson, M. Boutonnet, I. Melián-Cabreara, R. M. Navarro, and J. L. G. Fierro (2003) Production of hydrogen from methanol over $\mathrm{Cu} / \mathrm{ZnO}$ catalysts promoted by $\mathrm{ZrO}_{2}$ and $\mathrm{Al}_{2} \mathrm{O}_{3}$. J Catal 219: 389-403.

[10] Lindström, B., and L. J. Pettersson (2001) Hydrogen generation by steam reforming of methanol over copper-based catalysts for fuel cell applications. Int J Hydrogen Energy. 26: 923-933.

[11] Agrell, J., M. Boutonnet, and J. L. G. Fierro (2003) Production of hydrogen from methanol over binary $\mathrm{Cu} / \mathrm{ZnO}$ catalysts: Part II. Catalytic activity and reaction pathways. Appl. Catal. A: Gen. 253: 213-223.

[12] Purnama, H., F. Girgsdies, T. Ressler, J. H. Schattka, R. A. Caruso, R. Scomäcker, and R. Schlögl (2004) CO formation/selectivity for steam reforming of methanol with a commercial $\mathrm{CuO} / \mathrm{ZnO} / \mathrm{Al}_{2} \mathrm{O}_{3}$ catalyst Catal Lett. . 94 61-68.

[13] Breen, J. P., and J. R. H. Ross (1999) Methanol reforming for fuel-cell applications: development of zirconia-containing $\mathrm{Cu}-\mathrm{Zn}-\mathrm{Al}$ catalysts. Catal. Today. 51 521-533.

[14] Günter, M. M., T. Ressler, R. E. Jentoft, and B. Bems (2001) Redox Behavior of Copper Oxide/Zinc Oxide Catalysts in the Steam Reforming of Methanol Studied by in Situ XRay Diffraction and Absorption Spectroscopy J. Catal. 203: 133-149. 
[15] Fukahori, S., H. Koga, T. Kitaoka, A. Tomoda, R. Suzuki, and H. Wariishi (2006) Hydrogen production from methanol using a $\mathrm{SiC}$ fiber-containing paper composite impregnated with $\mathrm{Cu} / \mathrm{ZnO}$ catalyst Appl. Catal. A: Gen. . 310 138-144.

[16] Fierro, G., M. L. Jacono, M. Inversi, P. Porta, F. Cioci, and R. Lavecchia (1996) Study of the reducibility of copper in $\mathrm{CuO}-\mathrm{ZnO}$ catalysts by temperature-programmed reduction. Appl. Catal. A: Gen. . 137 327-348.

[17] Fujitani, T., and J. Nakamura (2000) The chemical modification seen in the $\mathrm{Cu} / \mathrm{ZnO}$ methanol synthesis catalysts Appl. Catal. A: Gen. 191 111-129.

[18] Bowker, M., R. A. Hadden, H. Houghton, J. N. K. Hyland, and K. C. Waugh (1988) The mechanism of methanol synthesis on copper/zinc oxide/alumina catalysts J. Catal. . 109 263-273.

[19] Duprez, D., Z. Ferhat-Hamida, and M. M. Bettahar (1990) Surface mobility and reactivity of oxygen species on a copper-zinc catalyst in methanol synthesis J. Catal. . 124: 1-11.

[20] Yong-Feng, L., D. Xin-Fa, and L. Wei-Ming (2004) Effects of ZrO2-promoter on catalytic performance of $\mathrm{CuZnAlO}$ catalysts for production of hydrogen by steam reforming of methanol Int. J. Hydrogen Energy. 29: 1617- 1621.

[21] Szizybalski, A., F. Girgsdies, A. Rabis, Y. Wang, M. Niederberger, and T. Ressler (2005) In situ investigations of structure-activity relationships of a $\mathrm{Cu} / \mathrm{ZrO}_{2}$ catalyst for the steam reforming of methanol. J Catal. . 233: 297-307.

[22] Oguchi, H., T. Nishiguchia, T. Matsumotoa, H. Kanaia, K. Utania, Y. Matsumurab, and S. Imamura (2005) Steam reforming of methanol over $\mathrm{Cu} / \mathrm{CeO}_{2} / \mathrm{ZrO}_{2}$ catalysts. Appl Catal A: Gen. 281: 69-73.

[23] Oguchi, H., H. Kanai, K. Utani, Y. Matsumura, and S. Imamura (2005) $\mathrm{Cu}_{2} \mathrm{O}$ as active species in the steam reforming of methanol by $\mathrm{CuO} / \mathrm{ZrO}_{2}$ catalysts Appl. Catal. A 293 64-70.

[24] Cheng, W.-H., I. Chen, J.-S. Liou, and S.-S. Lin (2003) Supported Cu Catalysts with Yttria-Doped Ceria for Steam Reforming of Methanol Topics Catal. 22 225233.

[25] Liu, Y., T. Hayakawa, K. Suzuki, and S. Hamakawa (2001) Production of hydrogen by steam reforming of methanol over $\mathrm{Cu} / \mathrm{CeO}_{2}$ catalysts derived from $\mathrm{Ce}_{1-\mathrm{x}} \mathrm{Cu}_{x} \mathrm{O}_{2-\mathrm{x}}$ precursors Catal. Commun. . 2: 195-200.

[26] Pérez-Hernández, R., A. Gutiérrez-Martínez, and C. E. Gutiérrez-Wing (2007) Effect of $\mathrm{Cu}$ loading on $\mathrm{CeO}_{2}$ for hydrogen production by oxidative steam reforming of methanol. Int J Hydrogen Energy. 32: 2888-2894.

[27] Zhang, X., and P. Shi (2003) Production of hydrogen by steam reforming of methanol on $\mathrm{CeO}_{2}$ promoted $\mathrm{Cu} / \mathrm{Al}_{2} \mathrm{O}_{3}$ catalysts J. Mol. Catal. A: Chem. 194: 99-105.

[28] Pérez-Hernández, R., F. Aguilar, A.Gomés-Cortés, and G. Díaz (2005) NO reduction with $\mathrm{CH}_{4}$ or $\mathrm{CO}$ on $\mathrm{Pt} / \mathrm{ZrO}_{2}-\mathrm{CeO}_{2}$ catalysts. Catal. Today. 107-108: 175-180.

[29] Trovarelli, A., C. De-Leitenburg, M. Boaro, and G. Dolcetti (1999) The utilization of ceria in industrial catalysis. Catal. Today. 50: 353-367. 
[30] Mastalir, A., B. Frank, A. Szizybalski, H. Soerijanto, A. Deshpande, M. Niederberger, R. Schomacker, R. Schlogl, and T. Ressler (2005) Steam reforming of methanol over $\mathrm{Cu} / \mathrm{ZrO}_{2} / \mathrm{CeO}_{2}$ catalysts: a kinetic study J. Catal. 230 464-475.

[31] Ritzkopf, I., S. Vukojevic', C. Weidenthaler, J. D. Grunwaldt, and F. Smith (2006) Decreased $\mathrm{CO}$ production in methanol steam reforming over $\mathrm{Cu} / \mathrm{ZrO}_{2}$ catalysts prepared by the microemulsion technique Appl. Catal. Gen. A. 302 215-223.

[32] Breen, J. P., F. C. Meunier, and J. R. H. Ross (1999) Mechanistic aspects of the steam reforming of methanol over a $\mathrm{CuO} / \mathrm{ZnO} / \mathrm{ZrO}_{2} / \mathrm{Al}_{2} \mathrm{O}_{3}$ catalyst. Chem. Commun.: 22472248.

[33] Wang, L.-C., Q. Liu, M. Chen, Y.-M. Liu, Y. Cao, H.-Y. He, and K.-N. Fan (2007) Structural Evolution and Catalytic Properties of Nanostructured $\mathrm{Cu} / \mathrm{ZrO}$ Catalysts Prepared by Oxalate Gel-Coprecipitation Technique. J. Phys. Chem. C. 111 16549-16557.

[34] Yao, C.-Z., L.-C. Wang, Y.-M. Liu, G.-S. Wu, Y. Cao, W.-L. Dai, H.-Y. He, and K.-N. Fan (2006) Effect of preparation method on the hydrogen production from methanol steam reforming over binary $\mathrm{Cu} / \mathrm{ZrO}_{2}$ catalysts. Appl Catal A: Gen 297: 151-158.

[35] Lindström, B., L. J. Pettersson, and P. G. Menon (2002) Activity and characterization of $\mathrm{Cu} / \mathrm{Zn}, \mathrm{Cu} / \mathrm{Cr}$ and $\mathrm{Cu} / \mathrm{Zr}$ on g-alumina for methanol reforming for fuel cell vehicles Appl. Catal. Gen. A. 234 111-125.

[36] Jeong, H., K. Kim, T. Kim, C. Ko, H. Park, and I. Song (2006) Hydrogen production by steam reforming of methanol in a micro-channel reactor coated with $\mathrm{Cu} / \mathrm{ZnO} / \mathrm{ZrO}_{2} / \mathrm{Al}_{2} \mathrm{O}_{3}$ catalyst. J. Power Sources. 159 1296-1299.

[37] Pérez-Hernández, R., G. Mondragón-Galicia, D. Mendoza-Anaya, J. Palacios, C. Angeles-Chavez, and J. Arenas-Alatorre (2008) Synthesis and characterization of bimetallic $\mathrm{Cu}-\mathrm{Ni} / \mathrm{ZrO}_{2}$ nanocatalysts: $\mathrm{H}_{2}$ production by oxidative steam reforming of methanol. Int J Hydrogen Energy. 33: 4569-4576.

[38] Pérez-Hernández, R., A. Gutiérrez-Martínez, J. Palacios, M. Vega-Hernández, and V. Rodríguez-Lugo (2011) Hydrogen production by oxidative steam reforming of methanol over $\mathrm{Ni} / \mathrm{CeO}_{2}-\mathrm{ZrO}_{2}$ catalysts. Int J Hydrogen Energy. 36: 6601- 6608.

[39] López, P., G. Mondragón-Galicia, M. E. Espinosa-Pesqueira, D. Mendoza-Anaya, M. E. Fernández, A. Gómez-Cortés, J. Bonifacio, G. Martínez-Barrera, and R. PérezHernández (2012) Hydrogen production from Oxidative Steam Reforming of Methanol: Effect of the $\mathrm{Cu}$ and $\mathrm{Ni}$ Impregnation on $\mathrm{ZrO}_{2}$ and their molecular simulation studies. Int J Hydrogen Energy. 37: 9018-9027.

[40] Yang, Y., J. Ma, and E. Wu (2006) Production of hydrogen by steam reforming of ethanol over a $\mathrm{Ni} / \mathrm{ZnO}$ catalyst. Int J Hydrogen Energy. 31 877-882.

[41] Biswas, P., and D. Kunzru (2007) Steam reforming of ethanol for production of hydrogen over $\mathrm{Ni} / \mathrm{CeO}_{2}-\mathrm{ZrO}_{2}$ catalyst: Effect of support and metal loading Int $\mathrm{J}$ Hydrogen Energy 32 969-980. 
[42] Mariño, F. J., E. G. Cerrella, S. Duhalde, M. Jobbagy, and M. Lombarde (1998) Hydrogen from steam reforming of ethanol. Characterization and performance of copper-nickel supported catalysts. Int J Hydrogen Energy 23 1095-1101.

[43] Mariño, F. J., M. Boveri, G. Baronetti, and M. Lombarde (2001) Hydrogen production from steam reforming of bioethanol using $\mathrm{Cu} / \mathrm{Ni} / \mathrm{K} / \gamma-\mathrm{Al}_{2} \mathrm{O}_{3}$ catalysts. Effect of $\mathrm{Ni}$. Int $\mathrm{J}$ Hydrogen Energy 26 665-668.

[44] Sun, J., X.-P. Qui, F. Wu, and W.-T. Zhu (2005) $\mathrm{H}_{2}$ from steam reforming of ethanol at low temperaure over $\mathrm{Ni} / \mathrm{Y}_{2} \mathrm{O}_{3}, \mathrm{Ni} / \mathrm{La}_{2} \mathrm{O}_{3}$ and $\mathrm{Ni} / \mathrm{Al}_{2} \mathrm{O}_{3}$ catalysts for fuel cell application. Int. J. Hydrogen energy. 30: 437-445.

[45] Navarro, R. M., M. C. Álvarez-Galván, F. Rosa, and J. L. G. Fierro (2006) Hydrogen production by oxidative steam reforming of hexadecane over $\mathrm{Ni}$ and $\mathrm{Pt}$ catalysts supported on Ce/La-doped $\mathrm{Al}_{2} \mathrm{O}_{3}$ Appl. Catal. A: Gen. 297: 60-72.

[46] Xia, B. J., J. D. Holladay, R. A. Dagle, E. O. Jones, and Y. Wang (2005) Development of highly active $\mathrm{Pd}-\mathrm{ZnO} / \mathrm{Al}_{2} \mathrm{O}_{3}$ catalysts for microscale fuel processor applications. Chem Eng Technol. 28(4): 515-519.

[47] Iwasa, N., S. Masuda, N. Ogawa, and N. Takezawa (1995) Steam reforming of methanol over $\mathrm{Pd} / \mathrm{ZnO}$ : Effect of the formation of PdZn alloys upon the reaction. Appl Catal A: Gen. 125(1): 145-157.

[48] Karim, A. M., T. Conant, and A. Datye (2006) The role of PdZn alloy formation and particle size on the selectivity for steam reforming of methanol. J Catal 243(2): 420427.

[49] Pérez-Hernández, R., A. D. Avendaño, E. Rosas, and V. Rodríguez (2011) Hydrogen Production by Methanol steam reforming over $\mathrm{Pd} / \mathrm{ZrO}_{2}-\mathrm{TiO}_{2}$ catalysts. Topic Catal. . 54: 572-578.

[50] Haruta, M., T. Tsubota, T. Kobayashi, H. Kageyama, M. J. Genet, and B. Delmon (1993) Low-Temperature Oxidation of $\mathrm{CO}$ over Gold Supported on $\mathrm{TiO}_{2}$, a-Fe2 $\mathrm{O}_{3}$, and $\mathrm{Co}_{3} \mathrm{O}_{4}$. J. Catal. 144: 175.

[51] Trovarelli, C. A. (1996) Catalytic properties of ceria and $\mathrm{CeO}_{2}$-containing materials. Catal. Rev. Sci. Eng. . 38: 439.

[52] Andreeva, D., V. Idakiev, T. Tabakova, L. Ilieva, P. Falaras, A. Bourlinos, and A. Travlos (2005) Low-temperature water-gas shift reaction over $\mathrm{Au} / \mathrm{CeO}_{2}$ catalysts. Catal. Today. 72: 51-57.

[53] Fu, Q., H.Saltsburg, and M. Flytzani-Stephanopoulos (2003) Active non-metallic Au and Pt species on Ceria-based Water-gas shift Catalysts. Science 301: 935-938.

[54] Sandoval, A., A. Gómez-Cortés, R. Zanella, G. Díaz, and J. M. Saniger (2007) Gold nanoparticles: Support effects for the WGS reaction. J. Mol Catal A: Chemical. 278: 200.

[55] Scire, S., S. Minnico, C. Crisafulli, C. Satriano, and A. Pistone (2003) Catalytic combustion of volatile organic compounds on gold/cerium oxide catalysts. Appl. Catal. B: Environmental. 40: 43. 
[56] Panzera, G., V. Modafferi, S. Candamano, A. Donato, F. Frusteri, and P. L. Antonucci (2004) CO selective oxidation on ceria-supported Au catalysts for fuel cell application. J . Power Sources 135: 177.

[57] Manzoli, M., F. Boccuzzi, A. Chiorino, F. Vindigni, W. Deng, and M. FlytzaniStephanopoulos (2007) Spectroscopic features and reactivity of CO adsorbed on different $\mathrm{Au} / \mathrm{CeO}_{2}$ catalysts. J Catal 245: 308.

[58] Chang, F.-W., H.-Y. Yu, L. S. Roselin, and H.-C. Yang (2005) Production of hydrogen via partial oxidation of methanol over $\mathrm{Au} / \mathrm{TiO}_{2}$ catalysts. Appl. Catal. A: General 290: 138.

[59] Pérez-Hernández, R., A. Gutiérrez-Martínez, A. Mayoral, F. L. Deepak, M. E. Fernández-García, G. Mondragón-Galicia, M. Miki, and M. Jose-Yacaman (2010) Hydrogen Production by Steam Reforming of Methanol over a Ag/ZnO One Dimensional Catalyst. Advanced Materials Research. 132: 205-219.

[60] Pérez-Hernández, R., and C. Gutiérrez-Wing (2009) Design of new Ag-Au(1-D)-CeO2 catalysts for hydrogen production by steam reforming of methanol. EuropaCat IX, Salamanca, Spain. 1-3.

[61] Pérez-Hernández, R., A. Gutiérrez-Martínez, and C. Gutiérrez-Wing (2010) Hydrogen Production by Steam Reforming of Methanol over New Ag-Au(1-D)-CeO2 Catalyst. Mater. Res. Soc. Symp. Proc. Vol. 127, Materials Research Society. 127: 1-4.

[62] Pérez-Hernández, R., A. Gómez-Cortés, J. Arenas-Alatorre, S. Rojas, R. Mariscal, J. L. G. Fierro, and G. Díaz (2005) SCR of $\mathrm{NO}$ by $\mathrm{CH}_{4}$ on $\mathrm{Pt} / \mathrm{ZrO}_{2}-\mathrm{TiO}_{2}$ sol-gel catalysts. Catal. Today. 107-108: 149-156.

[63] Pérez-Hernández, R., L. C. Longoria, J. Palacios, M. M. Aguila, and V. Rodríguez (2008) Oxidative steam reforming of methanol for hydrogen production over $\mathrm{Cu} / \mathrm{CeO}_{2}-\mathrm{ZrO}_{2}$ catalysts. Energ Mater Mater Sci Eng Energ Syst. 3: 152-157.

[64] Pérez-Hernández, R., D. Mendoza-Anaya, M. E. Fernández, and A. GómezCortés (2008) Synthesis of mixed $\mathrm{ZrO}_{2}-\mathrm{TiO}_{2}$ oxides by sol-gel: Microstructural characterization and infrared spectroscopy studies of NOx. J. Mol Catal A: Chemical 281: 200-206.

[65] Arenas-Alatorre, J., A. Gómez-Cortés, M. Avalos-Borja, and G. Díaz (2005) Surface Properties of $\mathrm{Ni}-\mathrm{Pt} / \mathrm{SiO}_{2}$ Catalysts for $\mathrm{N}_{2} \mathrm{O}$ Decomposition and Reduction by $\mathrm{H}_{2}$. . J Phys Chem B. 109: 2371.

[66] Ratnasamy, P., D. Srinivas, C. V. V. Satyanarayana, P. Manikandan, R. SenthilKumaran, M. Sachin, and V. N. Shetti (2004) Influence of the support on the preferential oxidation of $\mathrm{CO}$ in hydrogen-rich steam reformates over the $\mathrm{CuO}-\mathrm{CeO}_{2}-\mathrm{ZrO}_{2}$ system. . J Catal. 221: 455-465.

[67] Harrison, P. G., I. K. Ball, W. Azelee, W. Daniell, and F. Goldfarb (2000) Nature and surface redox properties of copper(ii)-promoted cerium(IV) oxide COoxidation catalysts. Chem Mater. 12: 3715-3725.

[68] Turco, M., G. Bagnasco, U. Costantino, F. Marmottini, T. Montanari, G. Ramis, and G. Busca (2004) Production of hydrogen from oxidative steam reforming of methanol II. 
Catalytic activity and reaction mechanism on $\mathrm{Cu} / \mathrm{ZnO} / \mathrm{Al}_{2} \mathrm{O}_{3}$ hydrotalcite-derived catalysts. J. Catal. 228: 56.

[69] Hollins, P. (1992) Surf. Sci. Rep. . 16: 51.

[70] Sakakini, B. H., J. Tabatabaei, M. J. Watson, and K.C.Waugh (2000) J.Mol. Catal. A. 162 297.

[71] Nasser, H., Á. Rédey, T. Yuzhakova, and J. Kovács (2009) Thermal Stability and Surface Structure of $\mathrm{Mo} / \mathrm{CeO}_{2}$ and Ce-doped $\mathrm{Mo} / \mathrm{Al}_{2} \mathrm{O}_{3}$ Catalysts. Journal of Thermal Analysis and Calorimetry. 95 69-74.

[72] Tabakova, T., F. Boccuzzi, M. Manzoli, and D. Andreva (2003) FTIR study of lowtemperature water-gas shift reaction on gold/ceria catalyst. Appl Catal A: Gen. 252: 385397.

[73] Fu, Q., W. Deng, H. Saltsburg, and M. Flytzani-Stephanopoulos (2005) Activity and stability of low-content gold-cerium oxide catalysts for the water-gas shift reaction Appl. Catal. B: Environmental. 56: 57-68.

[74] Ilieva, L., G. Pantaleo, I. Ivanov, A. M. Venezia, and D. Andreeva (2006) Gold catalysts supported on $\mathrm{CeO}_{2}$ and $\mathrm{CeO}_{2}-\mathrm{Al}_{2} \mathrm{O}_{3}$ for $\mathrm{NOx}$ reduction by $\mathrm{CO}$ Appl. Catal. B: Environmental. 65: 101-109.

[75] Rodriguez, J. A., X. Wang, P. Liu, W. Wen, J. C. Hanson, J. Hrbek, M. Pérez, and J. Evans (2007) Gold nanoparticles on ceria: importance of $O$ vacancies in the activation of gold. Top. Catal. 44: 73-81.

[76] Croy, J. R., S. Mostafa, J. Liu, Y.-h. Sohn, and B. R. Cuenya (2007) Size dependent Study of $\mathrm{MeOH}$ decomposition over Size-selected Pt nanoparticles Synthesized via micelle Encapsulation. Catal. Lett. 118: 1.

[77] Zhang, Y., J. Deng, L. Zhang, W. Qiu, H. Dai, and H. He (2008) AuOx/Ce0.6 $\mathrm{Zr}_{0.3} \mathrm{Y}_{0.1} \mathrm{O}_{2}$ nano-sized catalysts active for the oxidation of methane Catal. Today. 139: 29-36.

[78] Zhang, X., H. Shi, and B.Q. Xu (2007) Comparative study of $\mathrm{Au} / \mathrm{ZrO}_{2}$ catalysts in $\mathrm{CO}$ oxidation and 1,3-butadiene hydrogenation Catal. Today. 122: 330-337.

[79] Guzman, J., and B. C. Gates (2004) Catalysis by Supported Gold: Correlation between Catalytic Activity for CO Oxidation and Oxidation States of Gold J. Am. Chem. Soc. 126: 2672-2673.

[80] Wang, X., J. A. Rodriguez, J. C. Hanson, D. Gamarra, A.Martínez-Arias, and M. Fernández-García (2008) Ceria-based Catalysts for the Production of H2 Through the Water-gas-shift Reaction: Time-resolved XRD and XAFS Studies. Top. Catal. 49: 8188.

[81] Guzman, J., S. Carrettin, J. C. Fierro-Gonzalez, Y. Hao, B. C. Gates, and A. Corma (2005) CO Oxidation Catalyzed by Supported Gold: Cooperation between Gold and Nanocrystalline Rare-Earth Supports Forms Reactive Surface Superoxide and Peroxide Species Angew. Chem. Int. Ed. 44: 4778-4781.

[82] Ahmed, S., and M. Krumpelt (2001) Hydrogen from hydrocarbon fuels for fuel cells. Int J Hydrogen Energy 26: 291. 
[83] Gazsi, A., T. Bánsági, and F. Solymosi (2009) Hydrogen formation in the reaction of methanol on supported Au catalysts. Catal. Lett. 131: 33.

[84] Fisher, I. A., and A. T. Bell (1999) A Mechanistic Study of Methanol Decomposition over $\mathrm{Cu} / \mathrm{SiO}_{2}, \mathrm{ZrO}_{2} / \mathrm{SiO}_{2}$, and $\mathrm{Cu} / \mathrm{ZrO}_{2} / \mathrm{SiO}_{2}$. J. Catal. . 184: 357.

[85] Burch, R. (2007) Gold catalysts for pure hydrogen production in the water-gas shift reaction: activity, structure and reaction mechanism Phys. Chem. Chem. Phys. 8: 54835500 . 